This report was prepared as an account of work sponsored by an agency of the United States Government. Neither the United States Government nor any agency thereof, nor any of their employees, makes any warranty, express or implied, or assumes any legal liability or responsibility for the accuracy, completeness, or usefulness of any information, apparatus, product, or process disclosed, or represents that its use would not infringe privately owned rights. Reference herein to any specific commercial product, process, or service by trade name, trademark, manufacturer, or otherwise does not necessarily constitute or imply its endorsement, recommendation, or favoring by the United States Government or any agency thereof. The views and opinions of authors expressed herein do not necessarily state or reflect those of the United States Government or any agency thereof.

\title{
ICPP Environmental Monitoring Report CY-1994
}

\author{
Environmental Support
}

Published May 1995
Idaho National Engineering Laboratory Lockheed Martin Idaho Technologies Idaho Falls, Idaho 83415

\author{
Prepared for the \\ U.S. Department of Energy \\ Assistant Secretary for Environmental Management \\ Under DOE Idaho Operations Office \\ Contract DE-AC07-94ID13223
}




\section{DISCLAIMER}

Portions of this document may be illegible electronic image products. Images are produced from the best available original document. 
TABLE OF CONTENTS

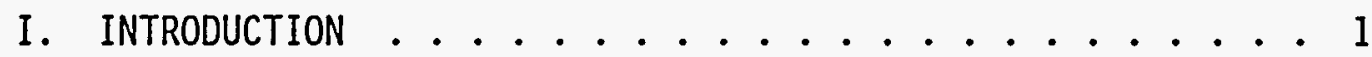

II. AIRBORNE MONITORING .............. 5

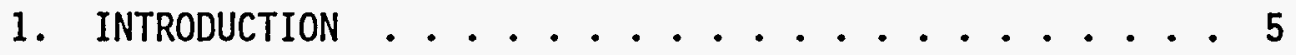

2. AIRBORNE RELEASES TO THE ENVIRONMENT . . . . . 5/6

2.1 Main Stack . . . . . . . . . . 5/6

2.2 FAST Stack ................ 18

2.3 NWCF Stack.............. . . 18

2.4 RAL Stack .............. . . . 18

2.5 Coal Fired Steam Generating Facility (CFSGF) . . . 18

III. LIQUID MONITORING . . . . . . . . . . . . . 30

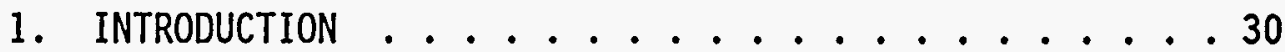

2. LIQUID RELEASES TO THE ENVIRONMENT . . . . . . 30

2.1 Service Waste System ......... 30

2.2 Production and Potable Water Wells .......41

2.3 Sewage Treatment Plant . . . . . . . . 41

2.4 ICPP Injection Wel1 ............... 41

FIGURES

1-1. SUMMARY OF AIRBORNE RELEASES ........... 3

1-2. SUMMARY OF LIQUID RELEASES . . . . . . . . . 4

2-1. MAIN STACK EFFLUENT - Total Activity . . . . . . 8

2-2. MAIN STACK EFFLUENT - I-129 . . . . . . . . 9

2-3. MAIN STACK EFFLUENT - Cs-137 .......... . 10

2-4. MAIN STACK EFFLUENT - Sr-90 . . . . . . . 11

2-5. MAIN STACK EFFLUENT - RU-106 . . . . . . . 12

2-6. MAIN STACK EFFLUENT - Pu-Total . . . . . . . 13

2-7. MAIN STACK EFFLUENT - Sb-125 . . . . . . . 14

2-8. MAIN STACK EFFLUENT - C-14 . . . . . . . 15

2-9. MAIN STACK EFFLUENT $-\mathrm{H}-3 \ldots \ldots$. . . . . . 16 
2-10. NO ${ }_{x}$ RELEASES FROM ICPP MAIN STACK . . . . . . . 17

2-11. FAST STACK EFFLUENT - Total Activity . . . . . . 20

2-12. FAST STACK EFFLUENT $-\mathrm{H}-3 \ldots \ldots . \ldots . \ldots . \ldots$

2-13. FAST STACK EFFLUENT - Pu-Totat . . . . . . . . 22

2-14. FAST STACK EFFLUENT - Sb-125 ........... 23

2-15. FAST STACK EFFLUENT - CS-137 . . . . . . . . . 24

2-16. NWCF STACK EFFLUENT - Total Activity . . . . . . . 26

2-17. RAL STACK EFFLUENT - Total Activity . . . . . . 28

3-1. SERVICE WASTE EFFLUENT - Total Activity . . . . . . 34

3-2. SERVICE WASTE EFFLUENT - TotaT-Pu . . . . . . . . 35

3-3. SERVICE WASTE EFFLUENT - TotaT-U . . . . . . . . 36

3-4. SERVICE WASTE EFFLUENT $-\mathrm{H}-3 \ldots \ldots$

3-5. SERVICE WASTE EFFLUENT - Ru-106 . . . . . . . 38

3-6. SERVICE WASTE EFFLUENT $-\mathrm{Sr}-90 \ldots 39$

3-7. SERVICE WASTE EFFLUENT - CS-137 .......... 40

3-8. SEWAGE TREATMENT PLANT - BOD, BOD Efficiency ..... . 45

3-9. SEWAGE TREATMENT PLANT - DO .............. 46

3-10. SEWAGE TREATMENT PLANT - $\mathrm{pH} \ldots \ldots . \ldots 47$

3-11. SEWAGE TREATMENT PLANT - Volume ........... . 48

TABLES

1-1. SUMMARY OF RELEASE DATA FOR $1994 \ldots \ldots$. . . . . . . . 2

2-1. AIRBORNE RELEASES FROM ICPP MAIN STACK - CY-1994 . . . 7

2-2. AIRBORNE RELEASES FROM ICPP FAST STACK - CY-1994 . . . 19

2-3. AIRBORNE RELEASES FROM ICPP NWCF STACK - CY-1994 . . . 25

2-4. AIRBORNE RELEASES FROM ICPP RAL STACK - CY-1994 . . . . 27

2-5. COAL FIRED STEAM GENERATING FACILITY - CY-1994 . . . . 29 
3-1. SERVICE WASTE RELEASES - CY-1994 . . . . . . . . . 31

3-2. SERVICE WASTE METALS - CY-1994 . . . . . . . . . 32

3-3. DCG RATIOS - DOE - CY-1994 ............ 33

3-4. PRODUCTION WELL - CY-1994 . . . . . . . . . . . 42

3-5. POTABLE WATER WELL - CY-1994 . . . . . . . . . 43

3-6. SEWAGE TREATMENT PLANT ANALYSIS - CY-1994 . . . . . . . 44

3-6. SEWAGE TREATMENT PLANT RADIONUCLIDE ANALYSIS - CY-1994 • 45 

BAT Best Available Technology

BOD Biological Oxygen Demand

CFSGF Coal Fired Steam Generating Facility .

DCGs Derived Concentration Guides

DO Dissolved Oxygen

DOE Department of Energy

EPA Environmental Protection Agency

FAST Fluorinel Dissolution Process \& Fuel Storage Facility

ICPP Idaho Chemical Processing Plant.

LITCO Lockheed Idaho Technologies Company

$\mathrm{NO}_{x} \quad$ Nitrogen Oxide

NWCF New Waste Calcining Facility

pH Potential of Hydrogen

QA Quality Assurance

QAPJP Quality Assurance Project Plan

RAL Remote Analytical Laboratory

STP Sewage Treatment PIant

$\mathrm{SO}_{2} \quad$ Sulfur Dioxide

VOG Ventilation Off-Gas 
ICPP ENVIRONMENTAL MONITORING REPORT

1994

\section{INTRODUCTION}

Summarized in this report are the data collected through Environmental Monitoring programs conducted at the Idaho Chemical Processing Plant (ICPP) by the Environmental Protection Department. This report is published in response to DOE Order 5400.1.

The ICPP is responsible for complying with all applicable Federal, State, Local and DOE Rules, Regulations and Orders. Radiological effluent and emissions are regulated by the DOE in accordance with the Derived Concentration Guides (DCGs) as presented in DOE Order 5400.5. The State of Idaho regulates nonradiological waste resulting from the ICPP operations including airborne, liquid, and solid waste.

The Environmental Department updated the Quality Assurance (QA) Project Plan for Environmental Monitoring activities during the third quarter of 1992. QA activities have resulted in the ICPP's implementation of the Environmental Protection Agency (EPA) rules and guidelines pertaining to the collection, analyses, and reporting of environmentally related samples. Where no EPA methods for analyses existed for radionuclides, LITCO methods were used.

Table 1-1 summarizes the volumes and activity released from ICPP stacks and liquid release points. Figure $1-1$ is a graphic representation of cumulative volume \& airborne releases and Figure 1-2 depicts cumulative volume \& liquid releases for the year. The graphs allow trends to be made of waste volume and activity released for the year. The Main Stack gaseous monitor was not in operation for 1994. New Waste Calcining Facility (NWCF) was not in operation in 1994. During 1994 the cumulative airborne and 7 iquid release of radionuclides was $8.81 \mathrm{E}-03$ curies. Airborne releases to the atmosphere contributed $2.92 \mathrm{E}-03$ curies and 7 iquid effluent released to the Percolation Pond contributed 5.89E-03 curies. Liquid Effluent Treatment and Disposal (LET\&D) began operation on January 1, 1993. PEW condensates which previously were discharged to Service Waste are now treated in the LET\&D facility. Table 3-1 and 3-2 provide information on radionuclide activity and concentration of inorganic chemicals present in the service waste. The values are compared to regulatory limits where applicable. 
Table 1-1

SUMMARY OF RELEASE DATA FOR 1994

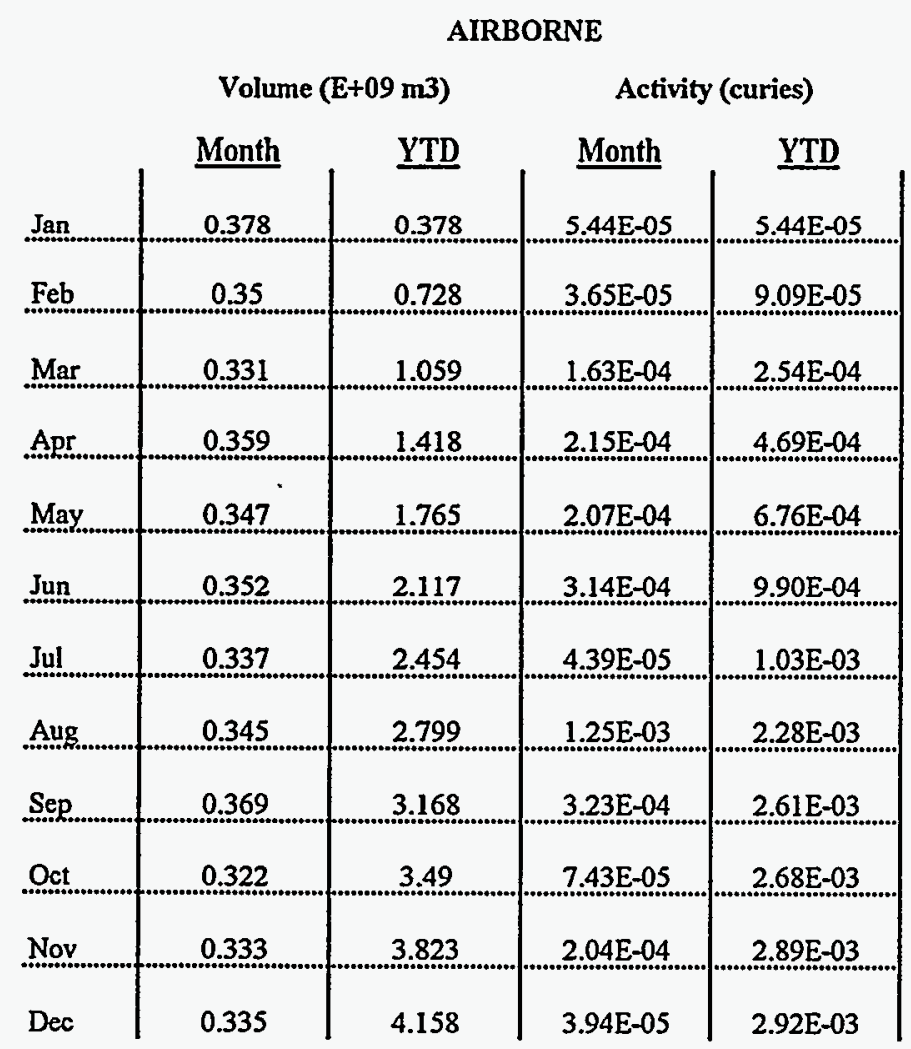

\begin{tabular}{|c|c|c|c|}
\hline \multicolumn{4}{|c|}{ LIQUID } \\
\hline \multicolumn{2}{|c|}{ Volume (E+09 L) } & \multicolumn{2}{|c|}{ Activity (curies) } \\
\hline Month & $\underline{\text { YTD }}$ & Month & YTD \\
\hline 0.222 & 0.222 & $6.36 E-04$ & $6.36 E-04$ \\
\hline 0.159 & 0.381 & 4.59E-04 & $1,10 E-03$ \\
\hline 0.208 & 0.589 & $5.50 \mathrm{E}-04$ & $1.65 \mathrm{E}-03$ \\
\hline 0.195 & 0.784 & $6.47 \mathrm{E}-04$ & $2.29 \mathrm{E}-03$ \\
\hline 0.201 & 0.985 & $5.12 \mathrm{E}-04$ & $2.80 \mathrm{E}-03$ \\
\hline .0.173 & 1.158 & ...47E-04 & $3.25 \mathrm{E}-03$ \\
\hline 0.145 & 1.303 & 4.33E-04 & $3.68 \mathrm{E}-03$ \\
\hline 0.15 & 1.453 & $3.56 \mathrm{E}-04$ & $4.04 \mathrm{E}-03$ \\
\hline 0.157 & 1.61 & 7.44E-04 & $4.78 \mathrm{E}-03$ \\
\hline 0.145 & 1.755 & 3.66E-04 & $5.15 E-03$ \\
\hline 0.158 & 1.913 & $\begin{array}{l}3.98 \mathrm{E}-04 \\
. .90 .9\end{array}$ & $5.55 \mathrm{E}-03$ \\
\hline 0.156 & 2.069 & $3.44 \mathrm{E}-04$ & $5.89 \mathrm{E}-03$ \\
\hline
\end{tabular}




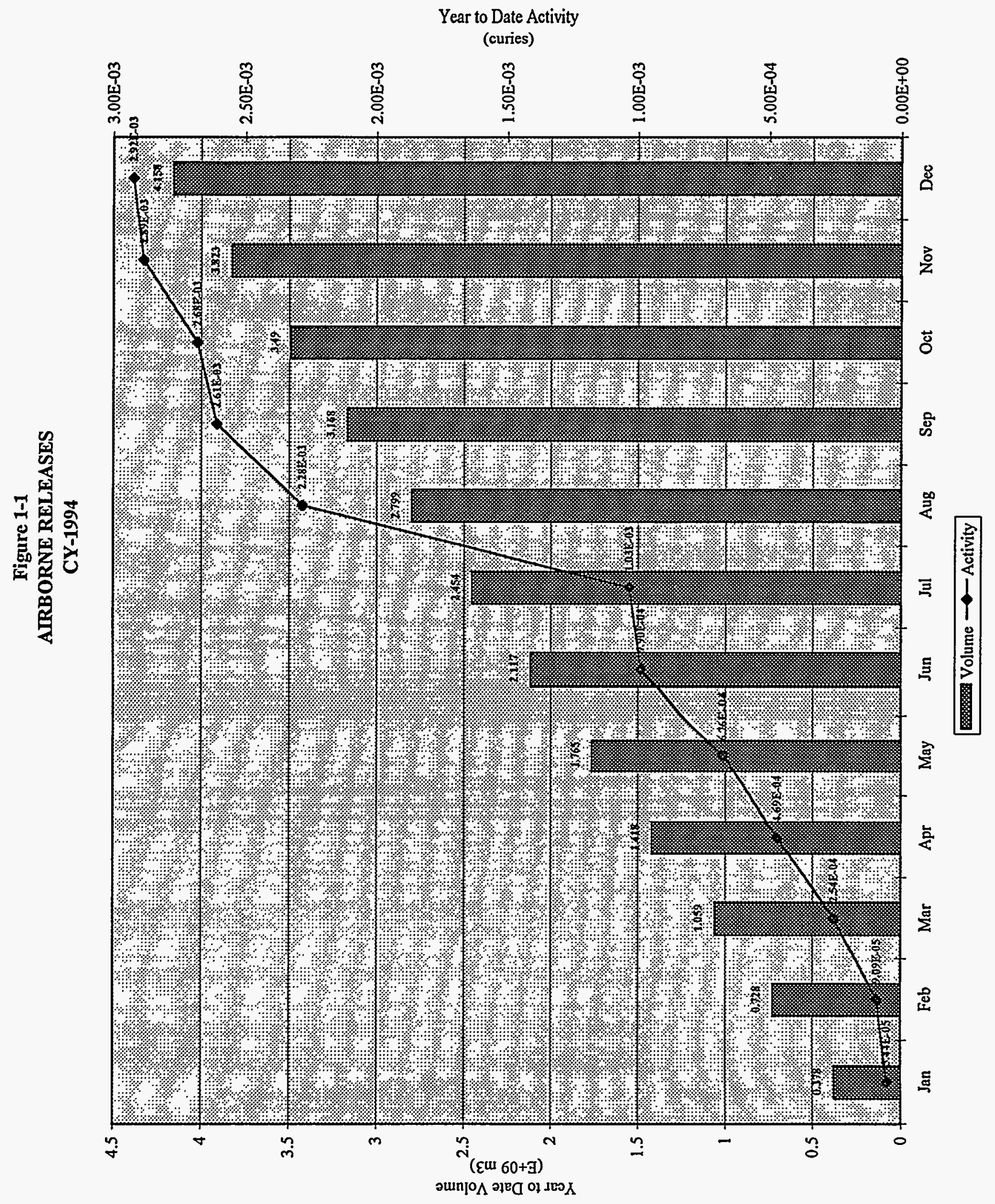


Figure 1-2

LIQUID EFFLUENT RELEASES

CY-1994

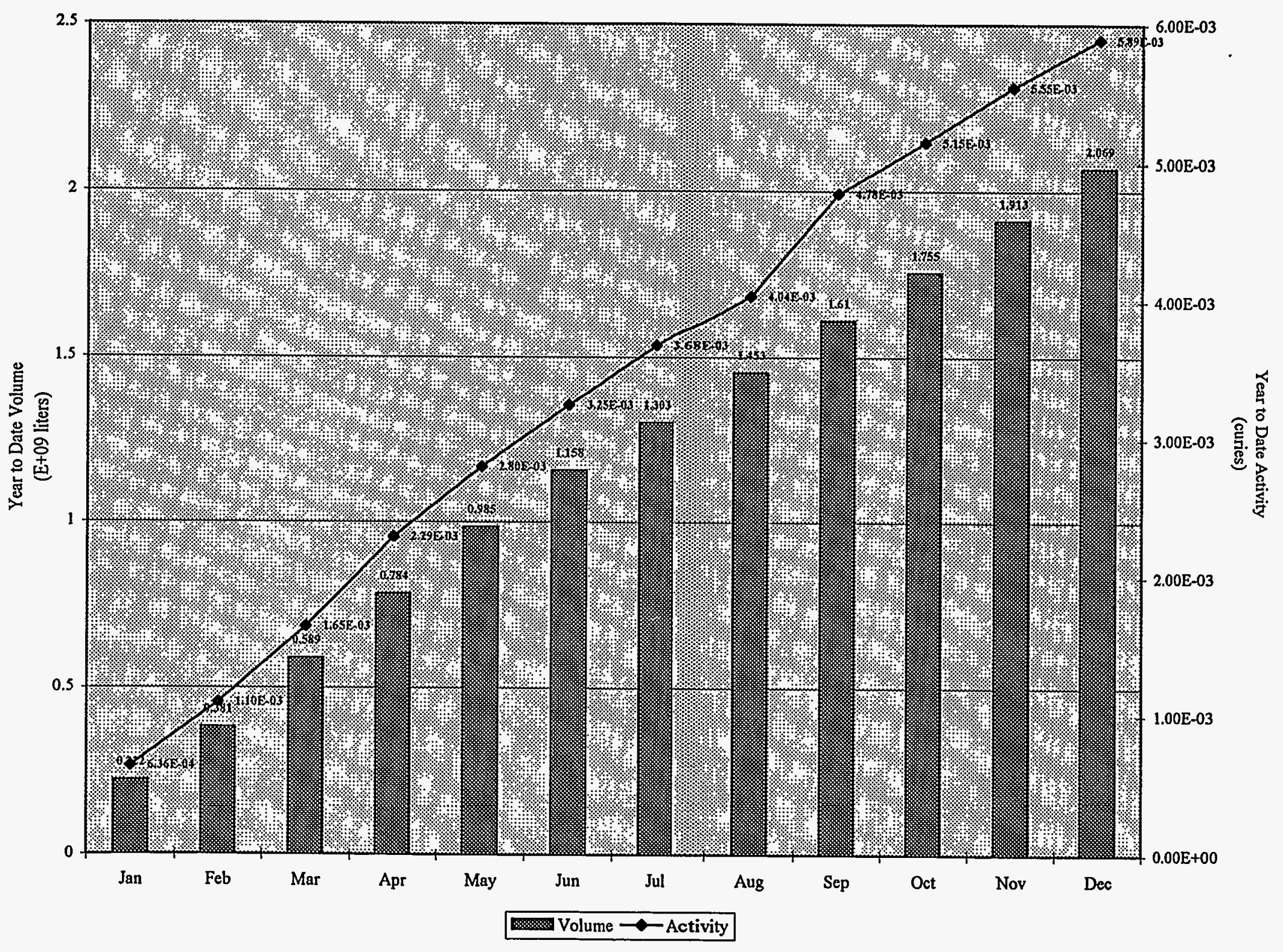




\section{AIRBORNE MONITORING}

\section{INTRODUCTION}

Airborne radioactive emissions are monitored from the Main Stack (CPP708), the Fluorinel Dissolution Process and Fuel Storage Facility (FAST) Stack (CPP-767), the New Waste Calcining Facility (NWCF) Stack (CPP-659), and the Remote Analytical Laboratory (RAL) Stack (CPP-684). NWCF was not in operation in 1994.

The Main Stack is equipped with radiological particulate and gaseous monitoring systems and the FAST Stack is equipped with a particulate monitoring system. The Main Stack gaseous monitor was not in operation in 1994. The airborne monitoring systems are based upon a proportional isokinetic sample. Particulate filters are collected and analyzed daily on the Main Stack. Nitrogen oxide ( $\mathrm{NO}_{\mathrm{x}}$ ) emissions are the only nonradioactive airborne contaminant that is monitored from the Main Stack.

Particulate filters for the RAL Stack were pulled and analyzed daily through October. Beginning in November 1994, filters are pulled and analyzed monthly. Particulate filters for the FAST Stack were collected and analyzed daily through September. Beginning in October 1994, filters are pulled and analyzed monthly.

The NWCF HVAC stack monitor filters are collected weekly and the Ventilation Off-Gas (VOG) system is continuously monitored for radioactive particulates. The CFSGF is monitored for $\mathrm{NO}_{x}, \mathrm{SO}_{2}$, carbon monoxide, and opacity in accordance with the State of Idaho, the EPA and the DOE-ID.

Radioactive releases for each emission point were we1l below the DOE DCGS for 1994. DCGs at the INEL boundary are reference values for conducting radiological environmental protection programs at operational DOE facilities and sites.

Quality assurance objectives for data measurement and laboratory performance are 1isted in the Quality Assurance Project P1an (QAPjP-001) for the Analysis of the Environmental Samples by both the LITCO CPP Analytical Labs and Radiation and Environmental Measurement Systems. Final data reduction is performed by the Environmental Support section of the Environmental Protection Department.

\subsection{Main Stack}

\section{AIRBORNE RELEASES TO THE ENVIRONMENT}

Airborne radioactive release data from the Main Stack for each month and the year are given in Table 2-1. This information is presented graphically in Figure 2-1. Graphic presentations showing yearly trends for radionuclides most 7 ikely to be present (iodine-129, cesium-137, strontium-90, ruthenium-106, plutonium (total), antimony$125, \mathrm{C}-14$, and $\mathrm{H}-3$ ), are given in Figures 2-2 through 2-9, respectively. I-129, $\mathrm{C}-14$, and $\mathrm{H}-3$ will have no results reported for 1994 because the gaseous monitor was not in operation. Also NWCF was not in operation during 1994 so no releases for those radionuclides are apparent. 
Main Stack (cont'd)

Nitrogen oxide ( $\mathrm{NO}_{\mathrm{x}}$ ) emission from the Main Stack is the only nonradioactive airborne contaminant continuously monitored. $\mathrm{NO}_{\mathrm{x}}$ concentration levels, while they do not violate any ambient air quality standard, must not exceed limits imposed by the FPR PSD permit. The limits set for the Main Stack are 388 pounds per hour and 1700 tons per year. Figure 2-10 provides $\mathrm{NO}_{\mathrm{x}}$ emissions for the last three years. The total $\mathrm{NO}_{\mathrm{x}}$ released in 1994 was 0 tons. 
ONILVYGdO YOLVALINGG*

\begin{tabular}{|c|c|c|c|c|c|c|c|c|c|c|c|c|c|}
\hline & $\begin{array}{l}\varepsilon 0-\Xi \angle \varepsilon \cdot \tau \\
80+\exists \angle I \cdot \tau\end{array}$ & $\varepsilon 0-\exists \varepsilon \varepsilon z$ & 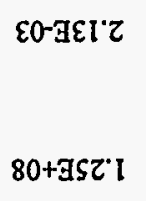 & $\begin{array}{l}\varepsilon 0-390 \cdot z \\
80+3 \angle z^{\prime} I\end{array}$ & $80+392: I$ & $80+96 I^{\circ} I$ & $80+\square \not \tau \tau$ & $80+9 \angle Z^{\prime} I$ & $80+\exists L Z I$ & $\begin{array}{l}t 0-3 \angle Z \cdot Z \\
80+30 z \cdot I\end{array}$ & $80+30 \varepsilon^{\prime} !$ & $\begin{array}{l}\text { s0-ata.t } \\
80+70 \varepsilon^{* 1}\end{array}$ & 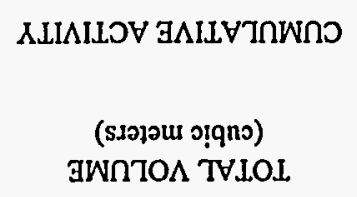 \\
\hline$\varepsilon 0-3 \angle E Z$ & $50-326 \bar{\varepsilon}$ & $00-a 100$ & $50-391 \%$ & 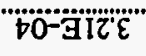 & $10-9068$ & so-äzi" to & " & 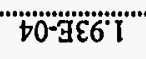 & "10-30" & "0-3901" & SO-GSSE & so-aitot & "XIAIIOV TVIOI" \\
\hline $00-3100$ & "so-azz" z" & $90-31901$ & so-asol $\mathrm{I}$ & $50-38 i t$ & $00-389$ & $90-3989$ & "to-3iti & $30-3907$ & $20-3096$ & & & & $06-15$ \\
\hline $50-38 z$ & $" 00=\mathrm{a} z Z 2 \mathrm{i}$ & $90-30 E \overline{1}$ & 1" & $90-3 \angle S 9$ & $90-3 \angle 6{ }^{2}$ & $\angle 0-\exists 9 \varepsilon z$ & "Lo-3ES" & $90-366 \mathrm{I}$ & $90-3281$ & $90-311 z$ & $\angle 0-\exists \varepsilon S E$ & "0-381's & sZ̈l-qs \\
\hline$t 0-a \varepsilon t$ & $90-3 z \bar{I}$ & so-akE & $90-30 \angle \bar{s}$ & so-Gseb" & $B 0-\mathrm{a} \angle D^{1} \mathrm{i}$ & $90-3606$ & "SO-abE i" & "S0-36Es" & S0-3i & $50-380$ & so-981 i & $50-3866^{1}$ & $901-i \bar{y}$ \\
\hline $90-3 S T \mid E$ & $\angle 0-389 \mathrm{~s}$ & & & & $90-3857$ & & & & & & & & Biou-nd \\
\hline $20-30 \varepsilon \bar{b}$ & & $00-36 z$ & & & " & & & "80-aहा' & $80-3918$ & & & & "DSI-nG" \\
\hline & & & & & & & & & & & & & "ZSi-ng" \\
\hline $80-9601$ & 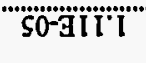 & $B 0=3 \nabla L i$ & $50=38 E S$ & " & $00-3 z 9$ & $s 0-3907$ & $s 0-310$ & " 0 - 3600 & $70-3 \angle 01$ & so-30Z6 & so-ažz & $50-395 z$ & "LE I-SD \\
\hline$s 0=3 z i 1$ & & $90-350 \%$ & $00-38 L \bar{\varepsilon}$ & "90-قัตร & $90-38 \varepsilon 6$ & $80-3955$ & $\angle 0-3 z 8$ & $00-3266$ & " & $20-388$ & " & $20-3991$ & "DEII-SJ" \\
\hline$\angle 0-3 \angle 9$ & $80-379$ & & & & $\angle 0-3 E S T$ & & & & $80-39 L \bar{\varepsilon}$ & & & & $09-00$ \\
\hline $80-3 \varepsilon 65$ & & & & & 80-قूहै t" & & & $80-3051$ & & & & & $\angle S-00$ \\
\hline TVIOL & วHם & $\Lambda O N$ & ע & das & *.onv & Tne & NnR & XVW & YdV & QVW & 89t & NFr & SaAITDNNOIAv8 \\
\hline
\end{tabular}


Figure 2-1

MAIN STACK EFFLUENT

Total Activity (curies)

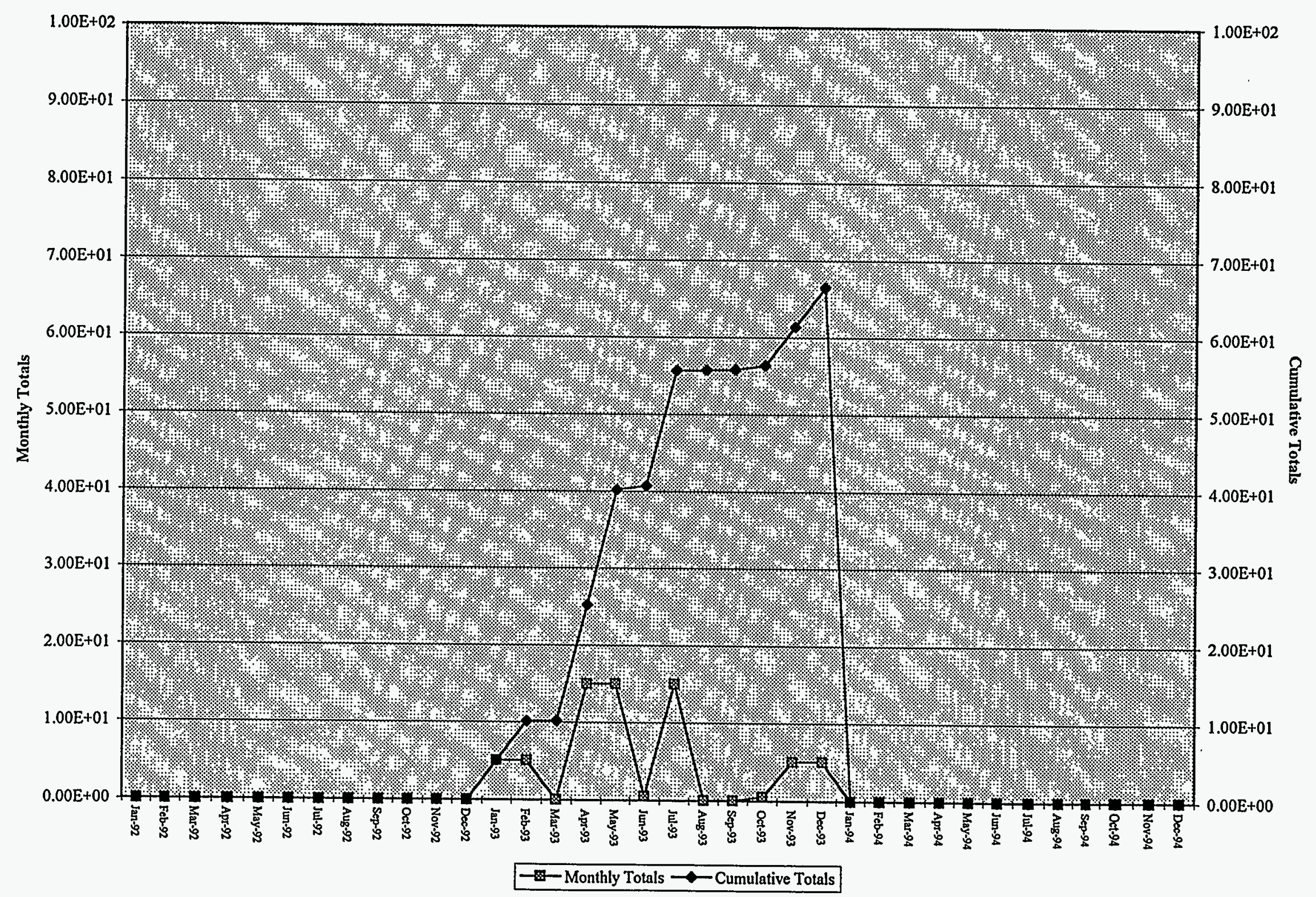


Figure 2-2

MAIN STACK EFFLUENT

I-129 (curics)

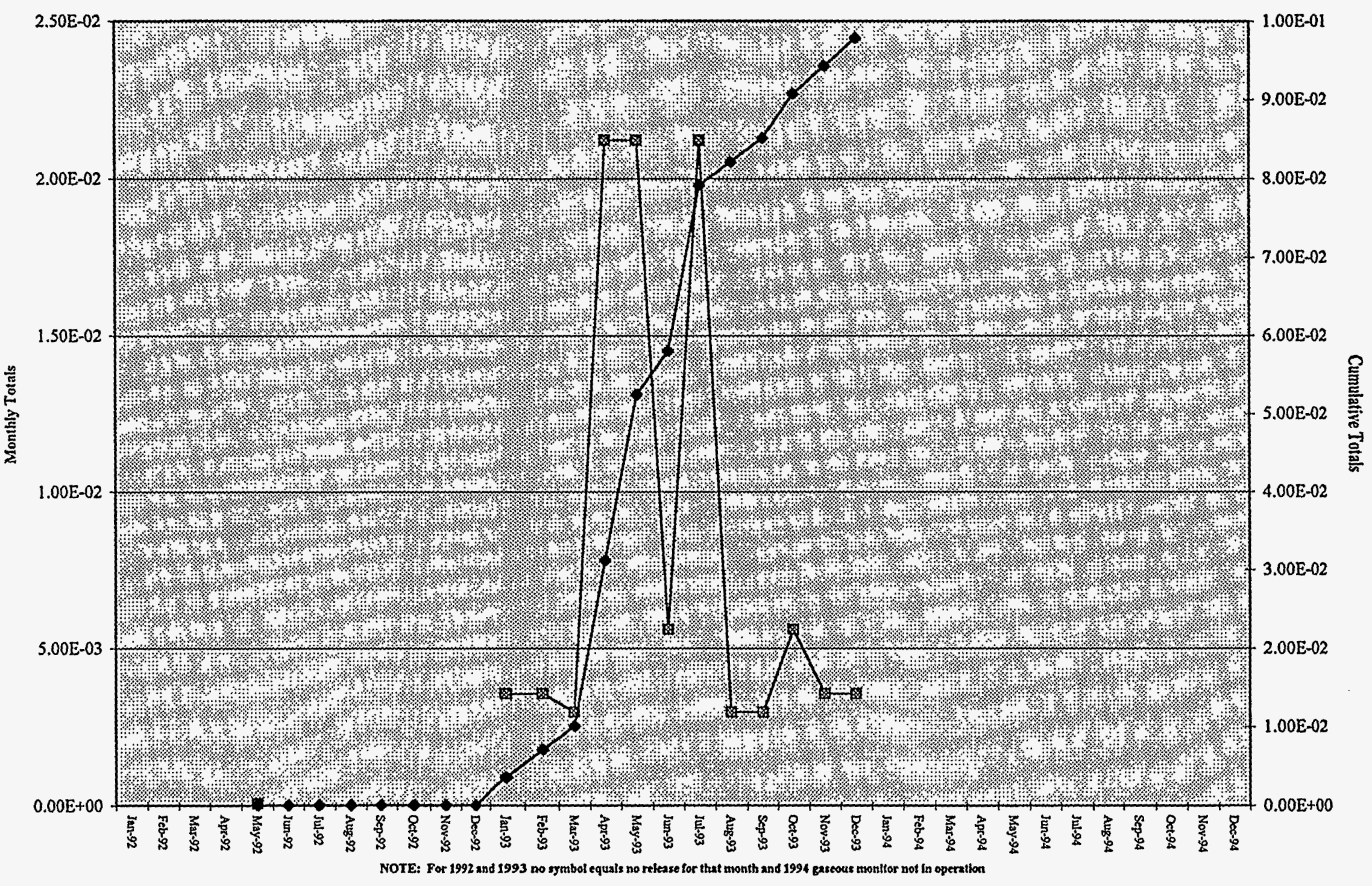




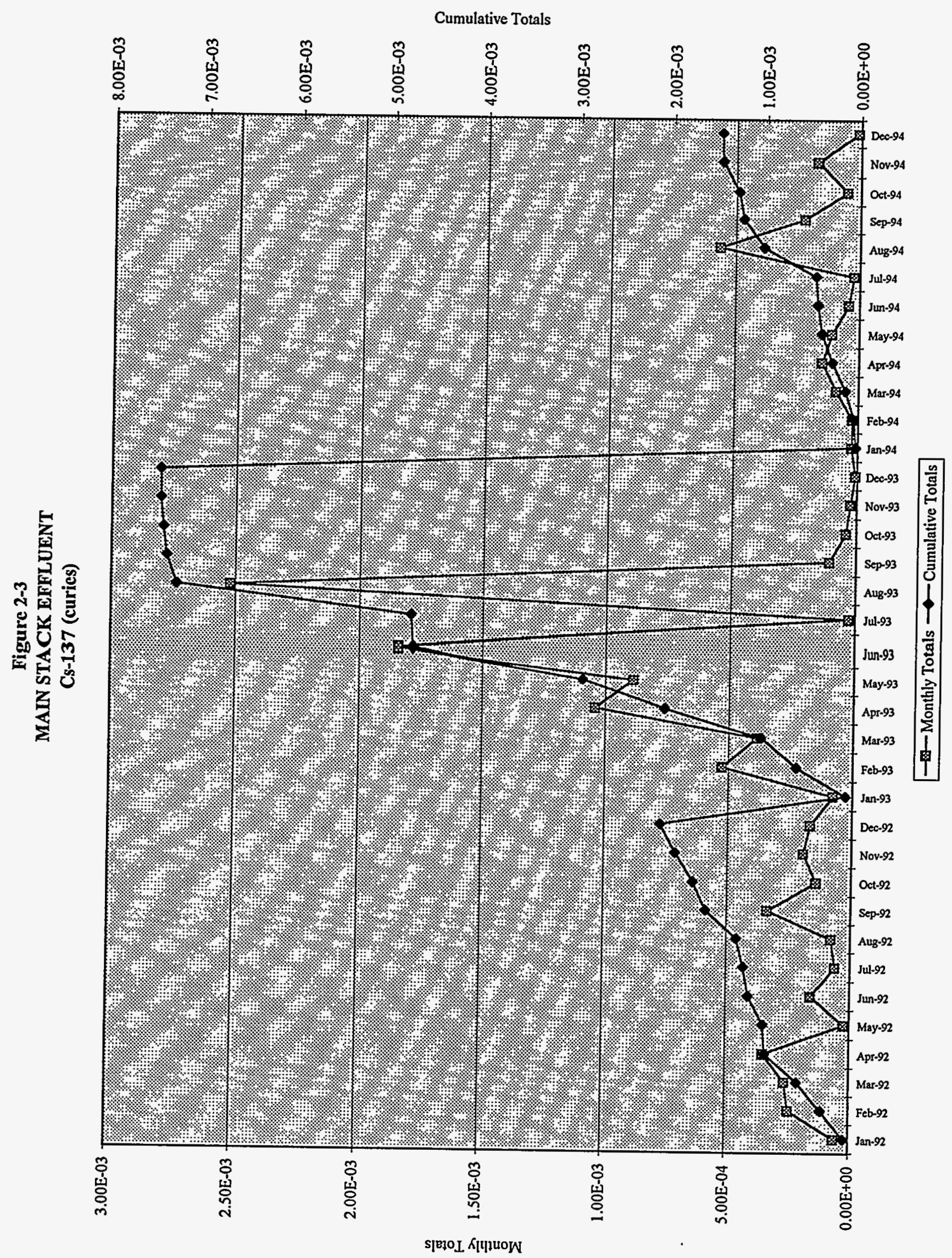




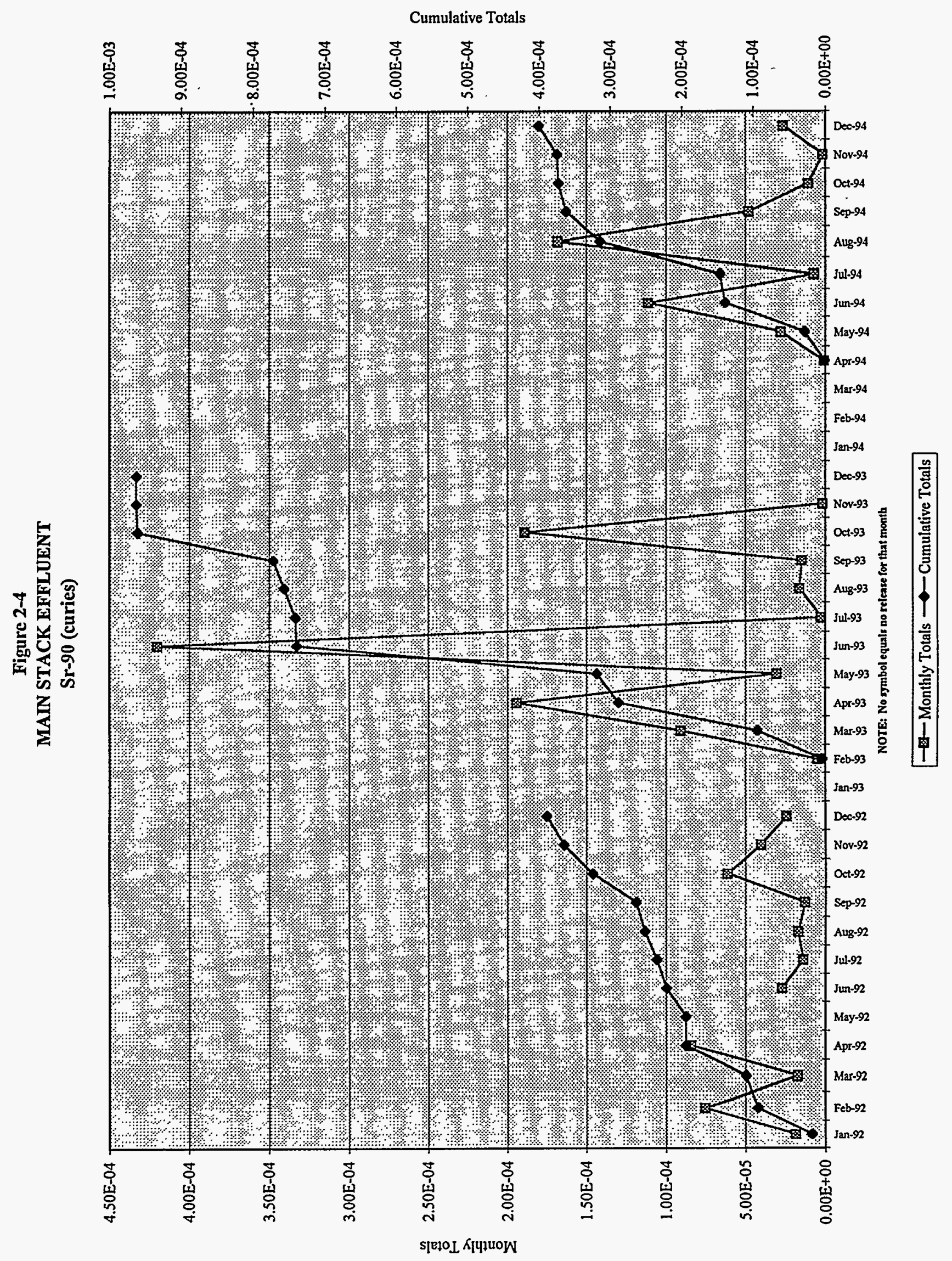




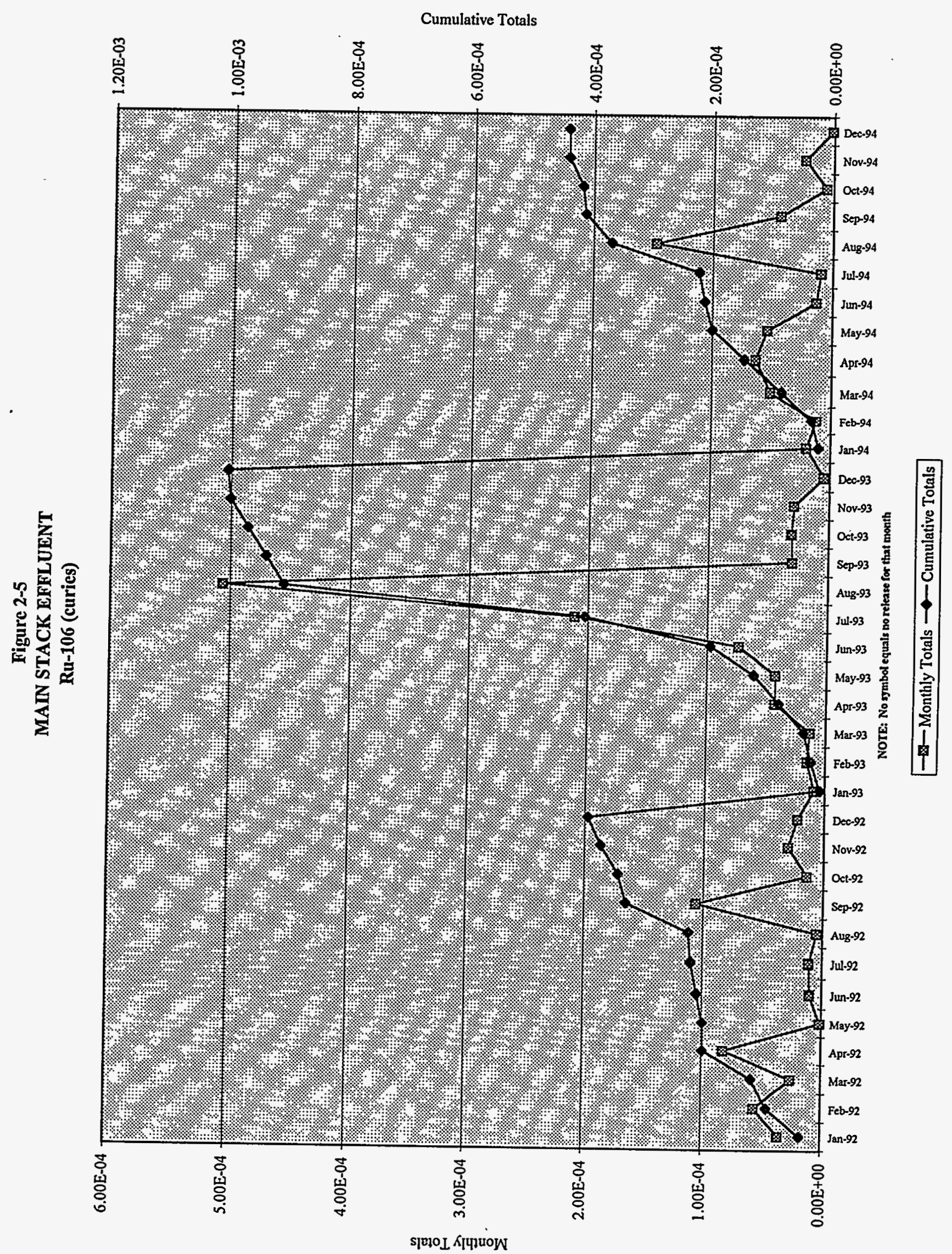




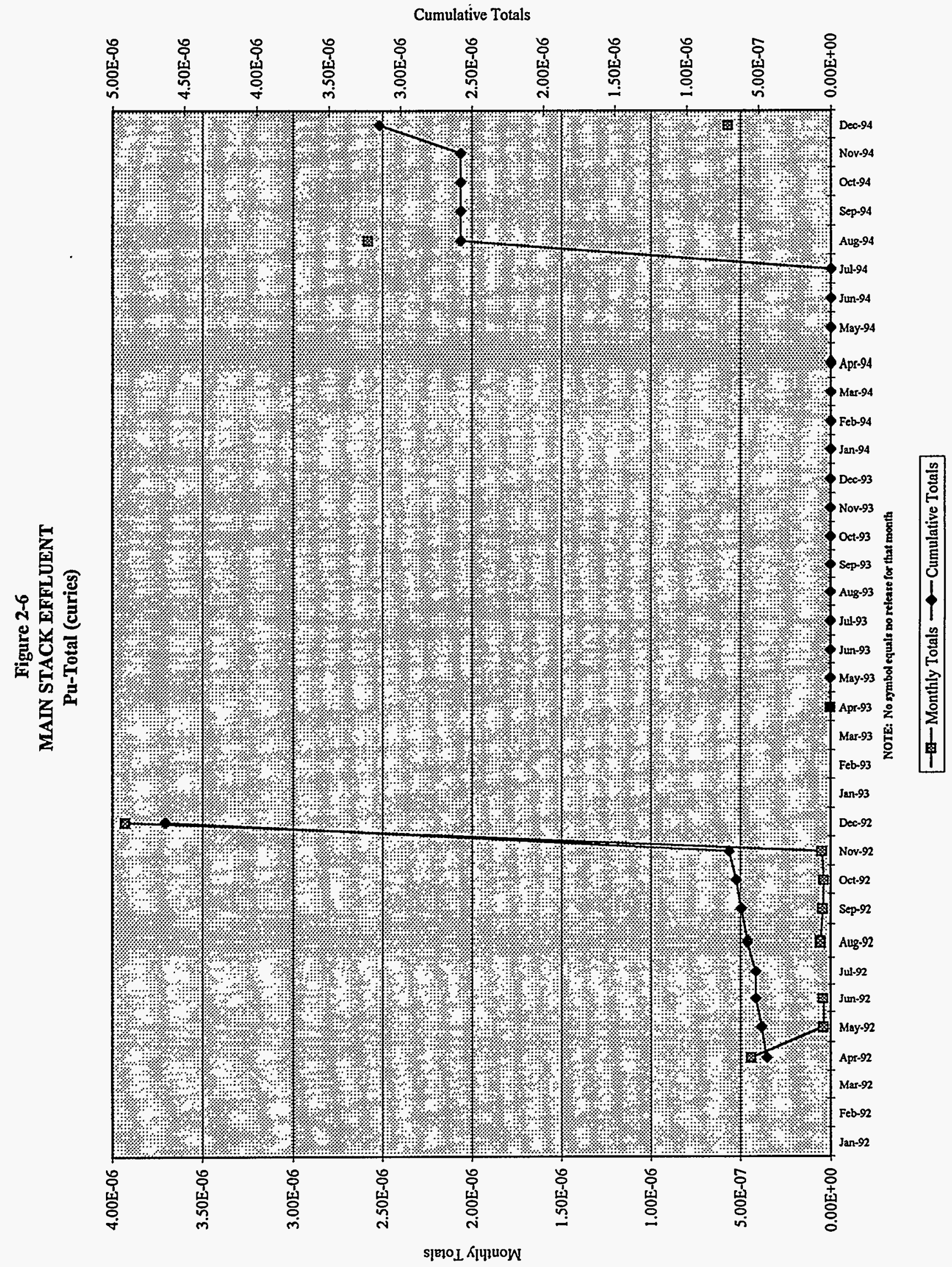




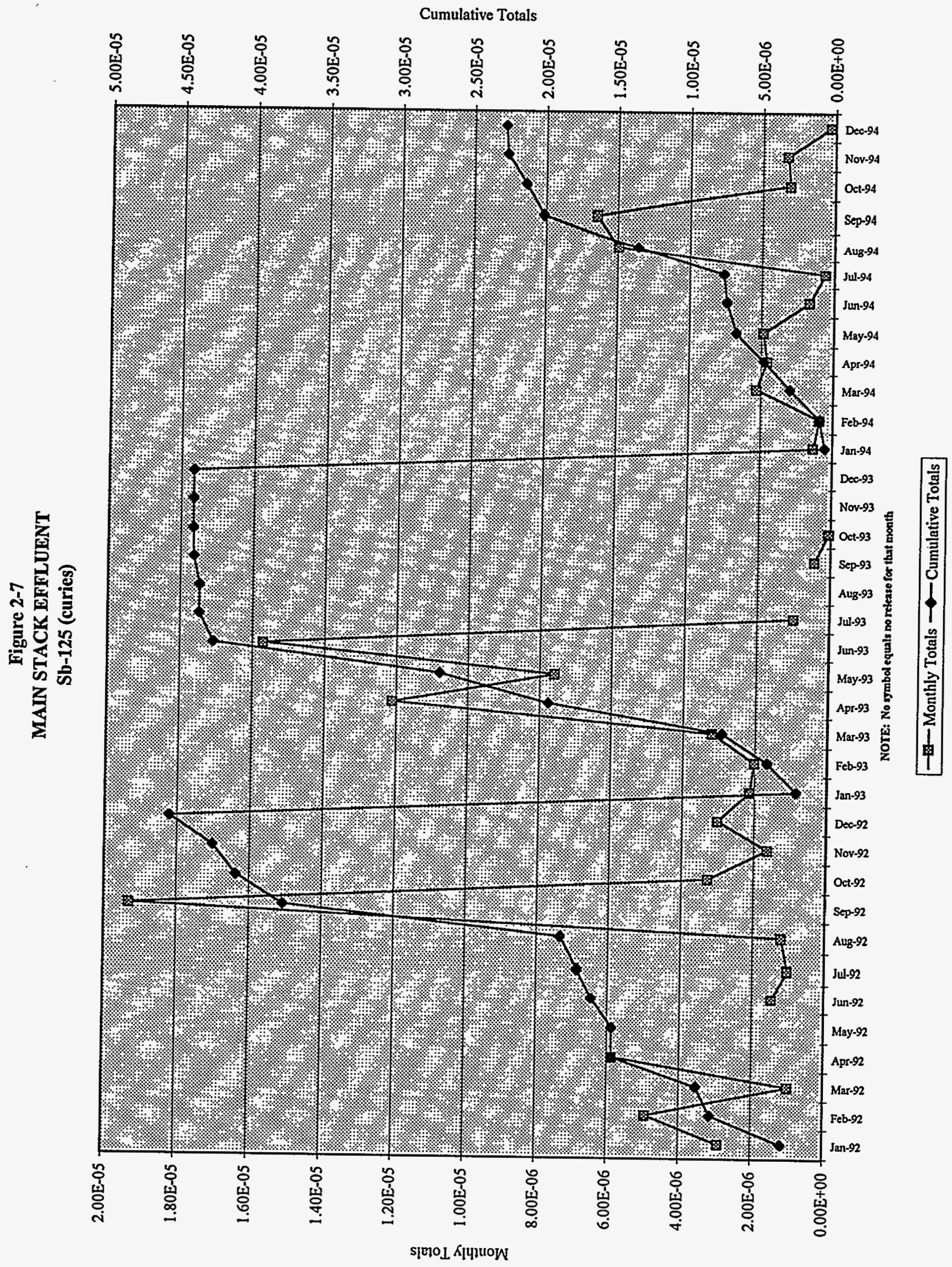




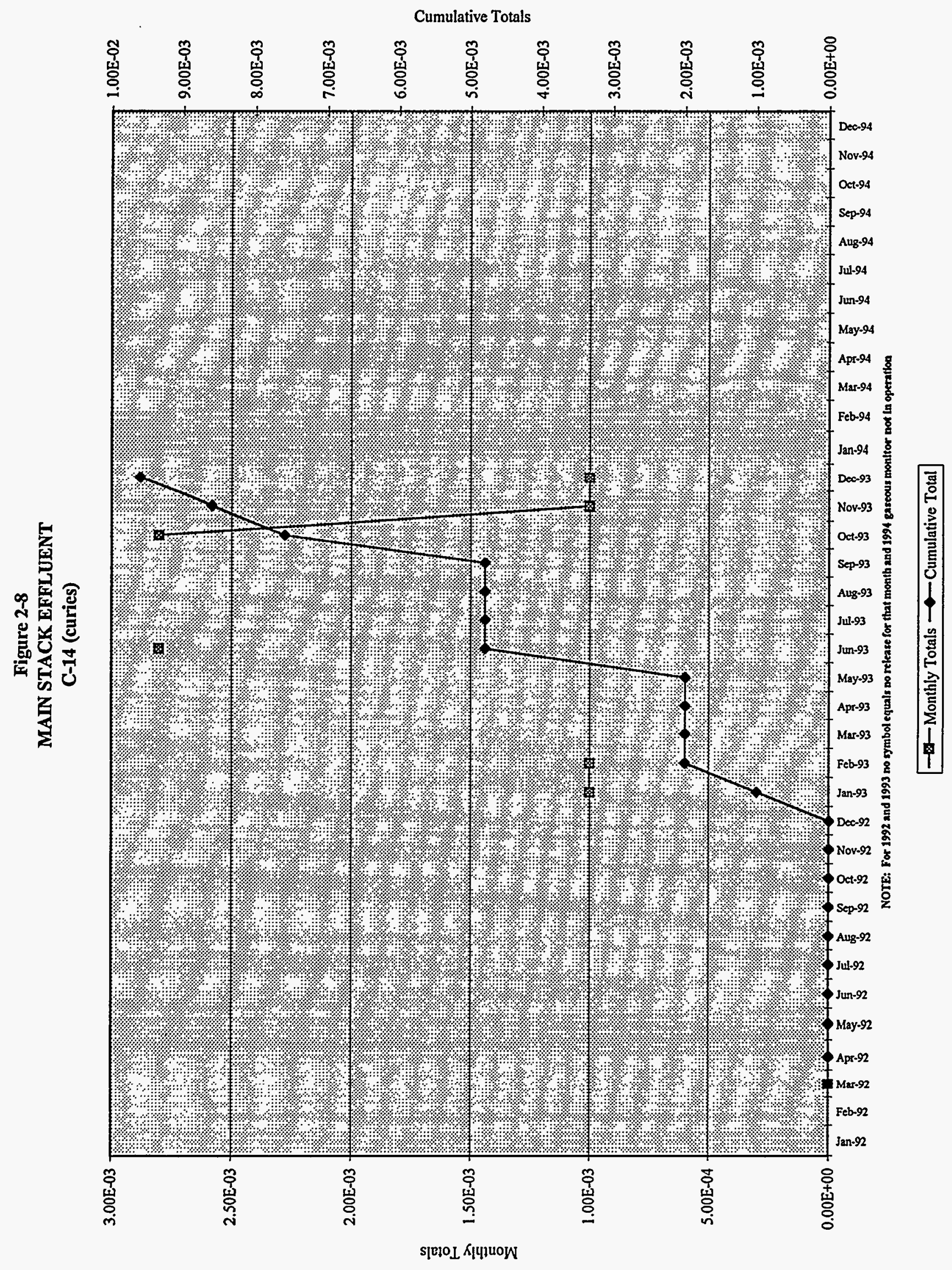




\section{Figure 2-9}

\section{MAIN STACK EFFLUENT}

H-3 (curies)

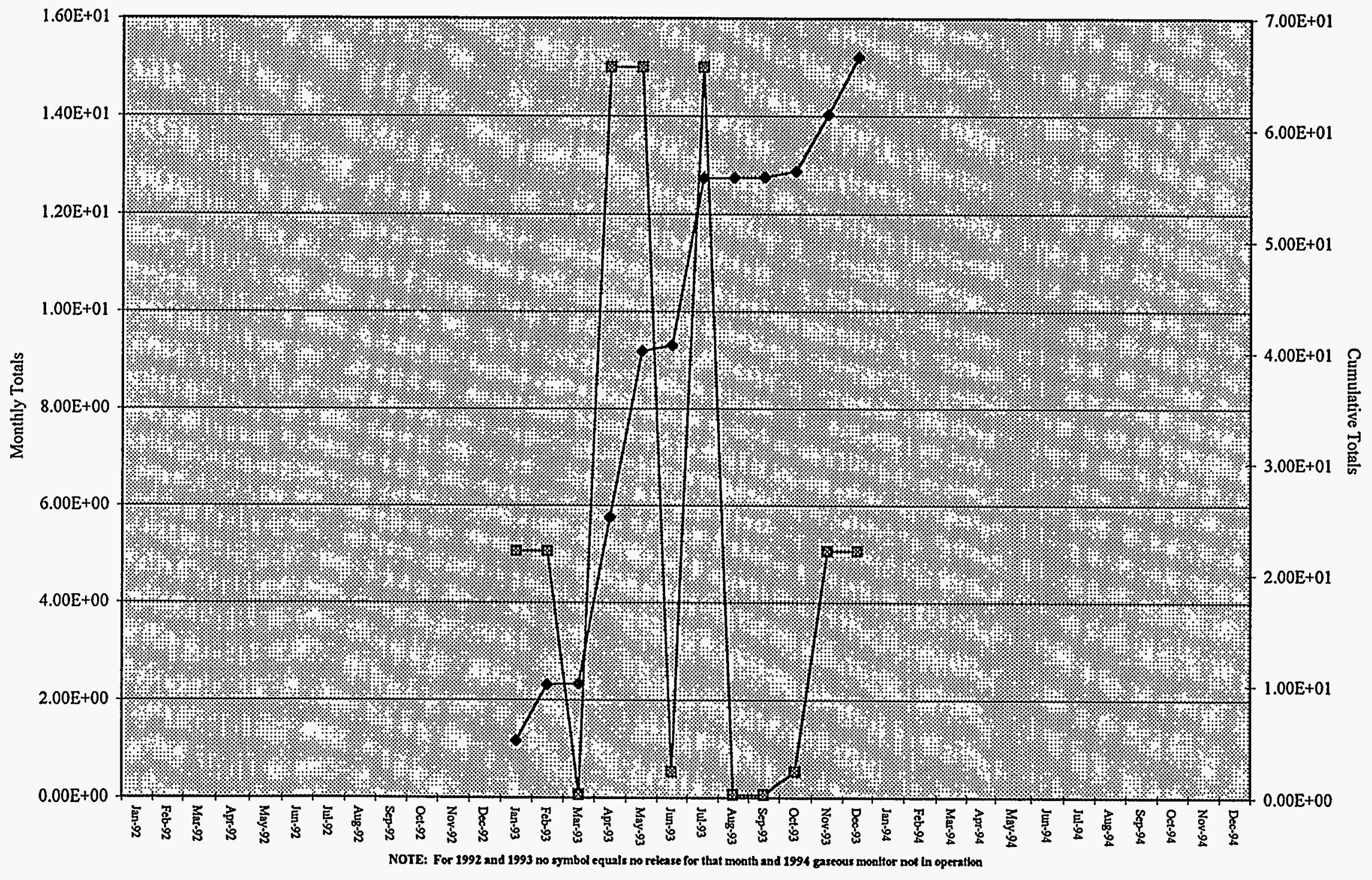


Figure 2-10

NOx Released from ICPP Main Stack (tons)

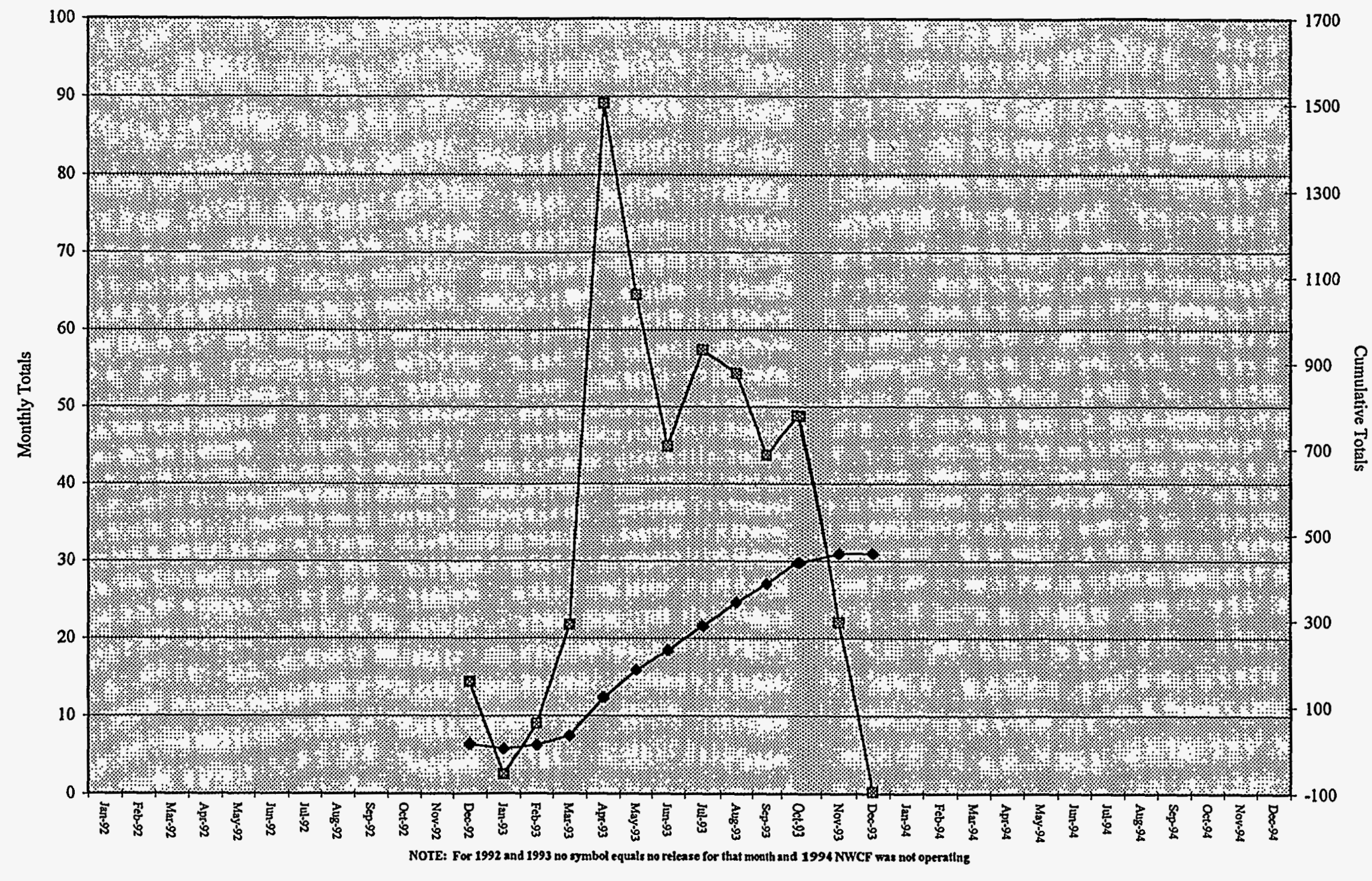




\subsection{FAST Stack}

Table 2-2 lists the total radionuclide releases in curies from the FAST Stack per month by radionuclide and Figure 2-11 depicts the total monthly activity. Graphic presentations for tritium $(H-3)$, plutonium (Total), antimony-125, and cesium 137 showing yearly trends are given in Figures 2-12 through 2-15, respectively.

\subsection{NWCF Stack}

Table 2-3 presents the radioactive emissions from the NWCF VOG system. The radionuclides reported are those that have been routinely analyzed for in the ventilation stack emissions. Figure 216 depicts the total monthly activity.

\subsection{RAL Stack}

Table 2-4 presents the radioactive emissions from the RAL VOG system. The radionuclides reported are those that have been identified in the ventilation stack emissions. Figure 2-17 depicts the total monthly activity.

\subsection{Coal Fired Steam Generating Facility (CFSGF)}

The CFSGF stack is monitored continuously for sulfur dioxide $\left(\mathrm{SO}_{2}\right)$, nitrogen oxide $\left(\mathrm{NO}_{x}\right)$, and opacity. Carbon monoxide (CO) is calculated by using AP-42 emission factors and fuel consumption rates. Emission limits for the stack are set by the Environmental Protection Agency (EPA) and the State of Idaho. Table 2-5 1ists the releases per month for the CFSGF. The facility must provide a minimum removal efficiency of $70 \%$ for $\mathrm{SO}_{2}$ calculated as an average over a 30 day period. $\mathrm{SO}_{2}$ emissions shafl not exceed an average of 0.6 pounds per MM/Btu of fuel input averaged over a 24 hour period. NO ${ }_{x}$ emissions shall not exceed an average of 0.5 pounds per MM/Btu of fuel input averaged over a 24 hour period when the steam load is equal to or greater than 35,000 pounds per hour. $\mathrm{NO}_{\mathrm{x}}$ emissions shall not exceed 0.7 pounds per MM/Btu of fuel input averaged over a 24 hour period when the steam load is less than 35,000 pounds per hour. Carbon monoxide shall not exceed $148.5 \mathrm{lbs} / \mathrm{hr}$ or 650.4 tons/yr. Opacity 1 imit for the CFSGF is $20 \%$. 


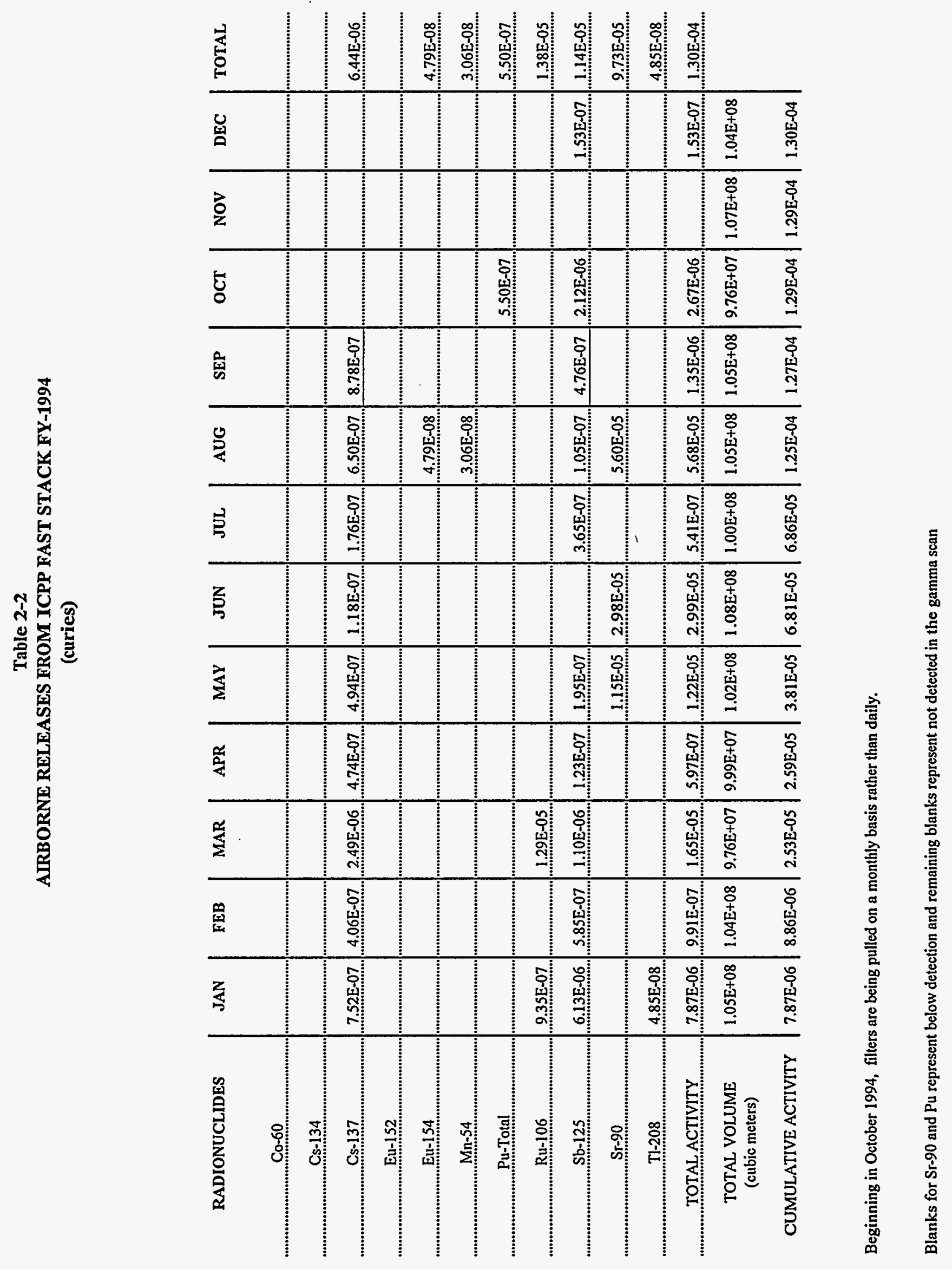




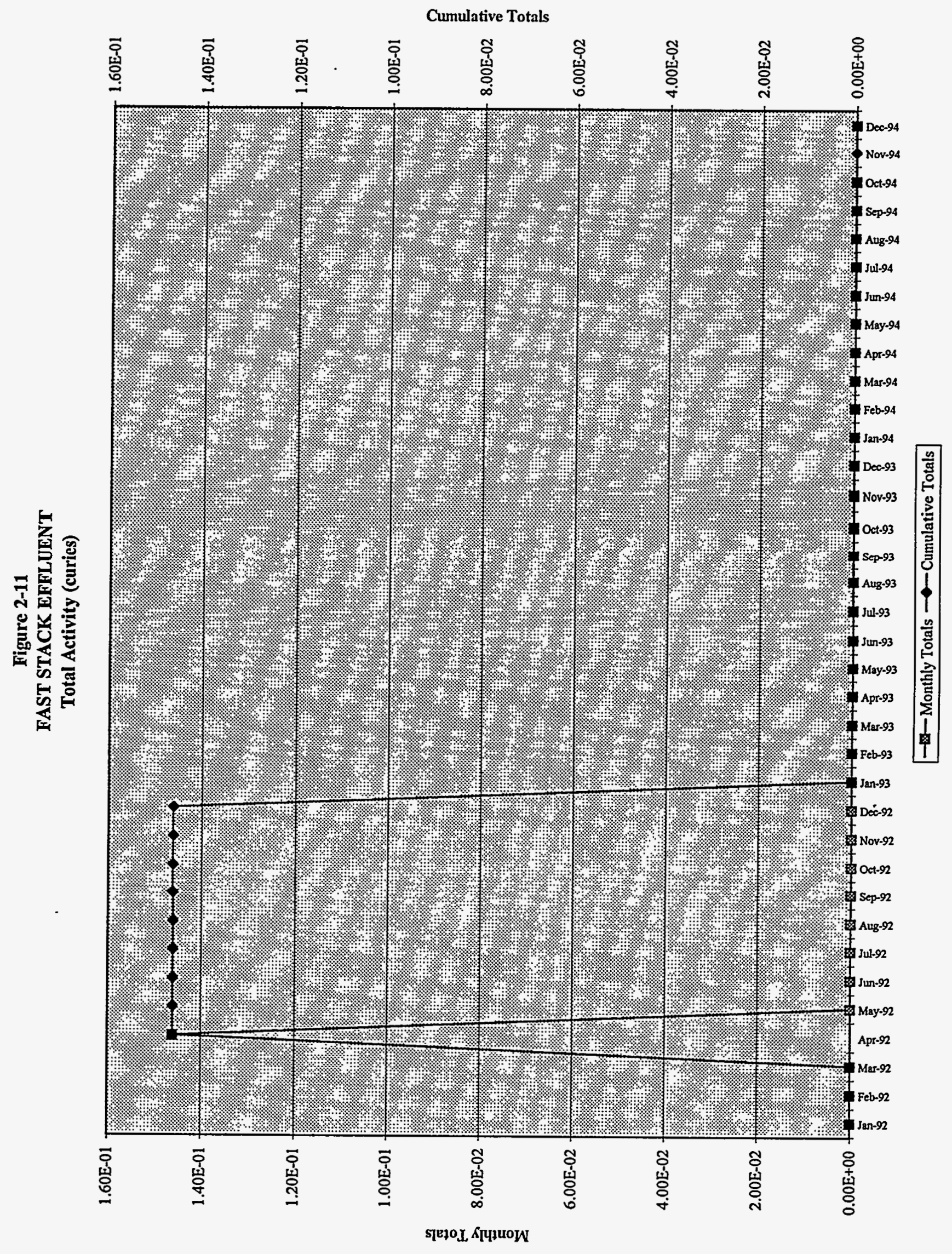


Figure 2-12

FAST STACK EFFLUENT

H-3 (curies)

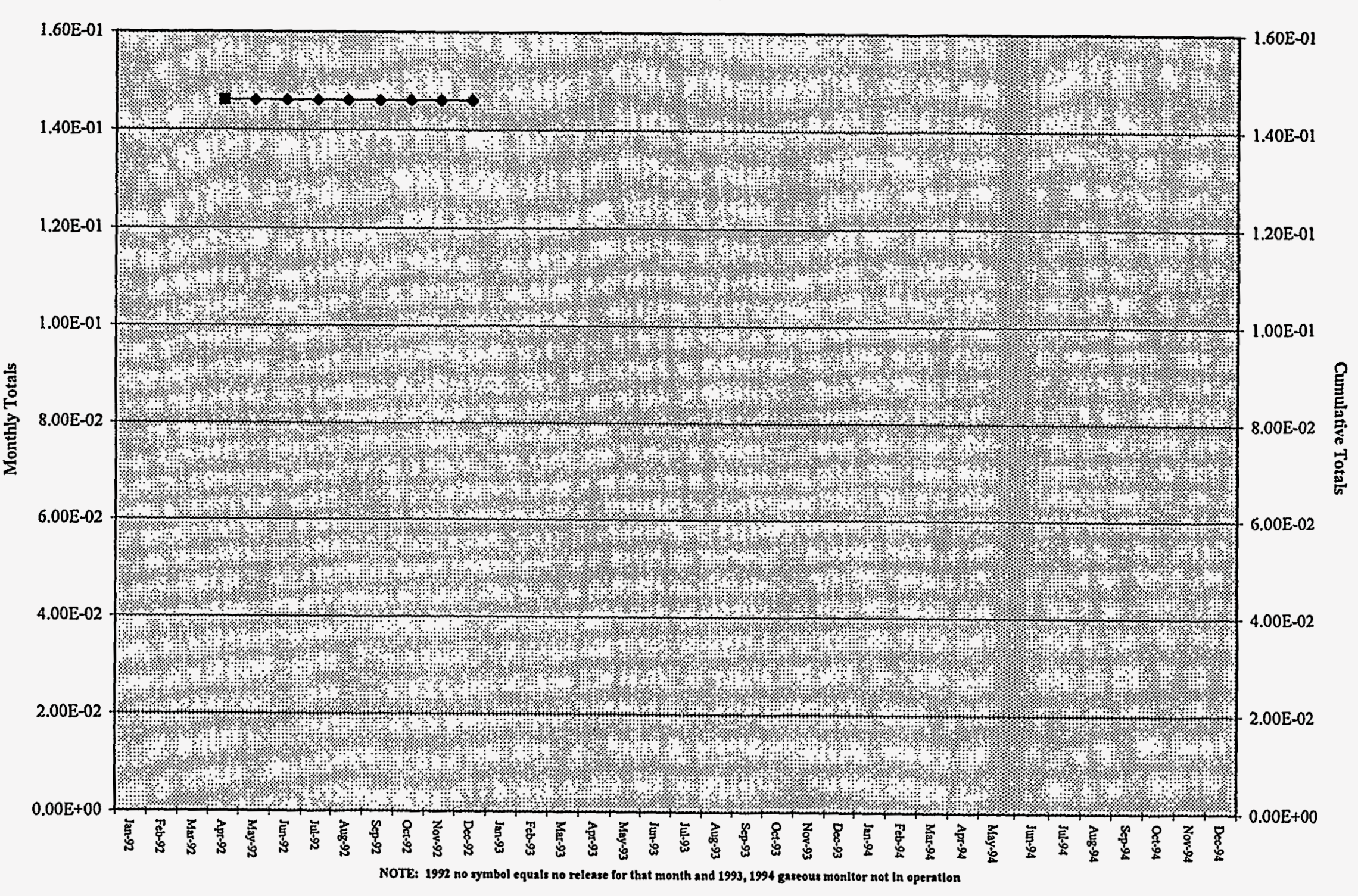




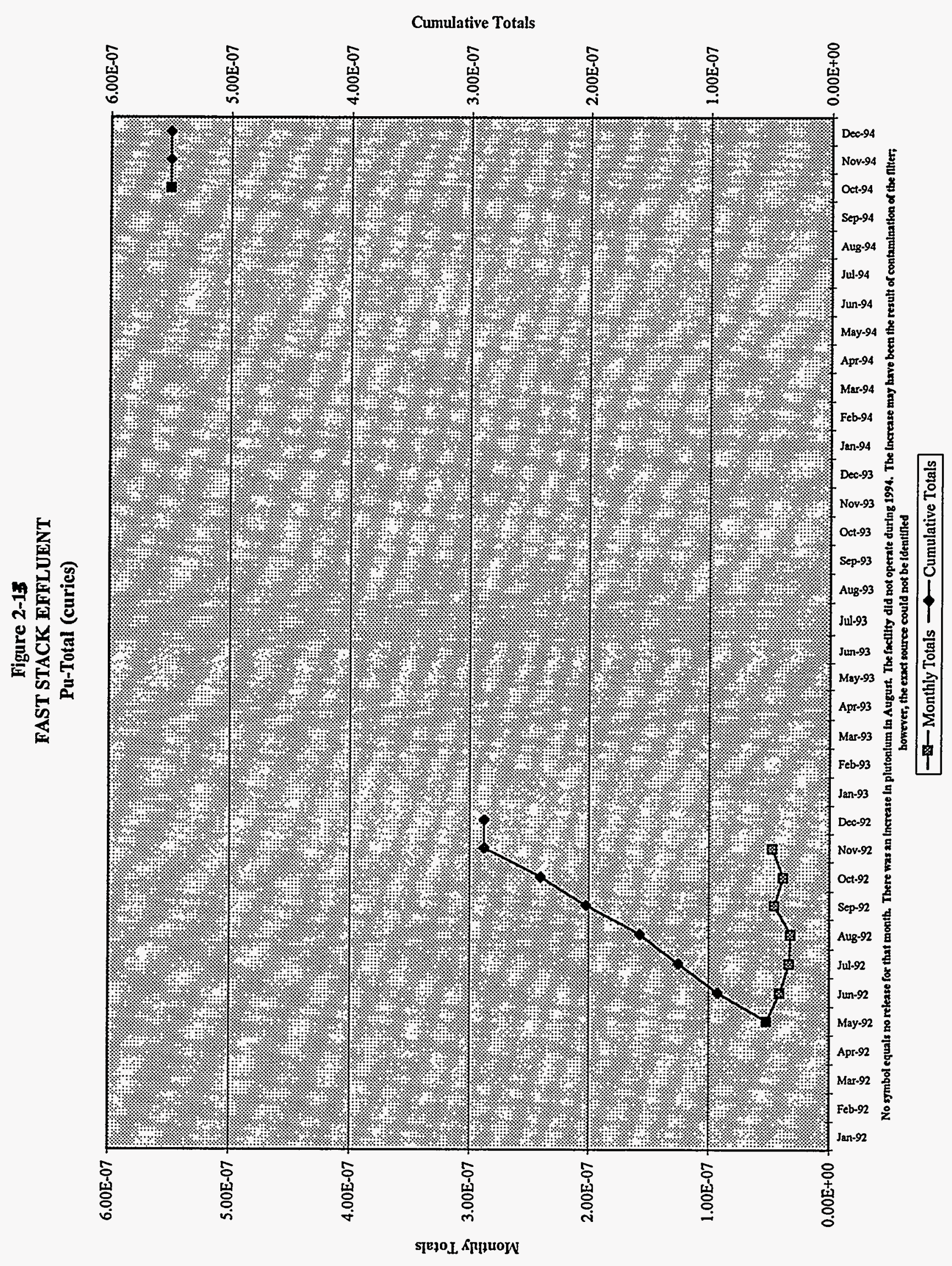




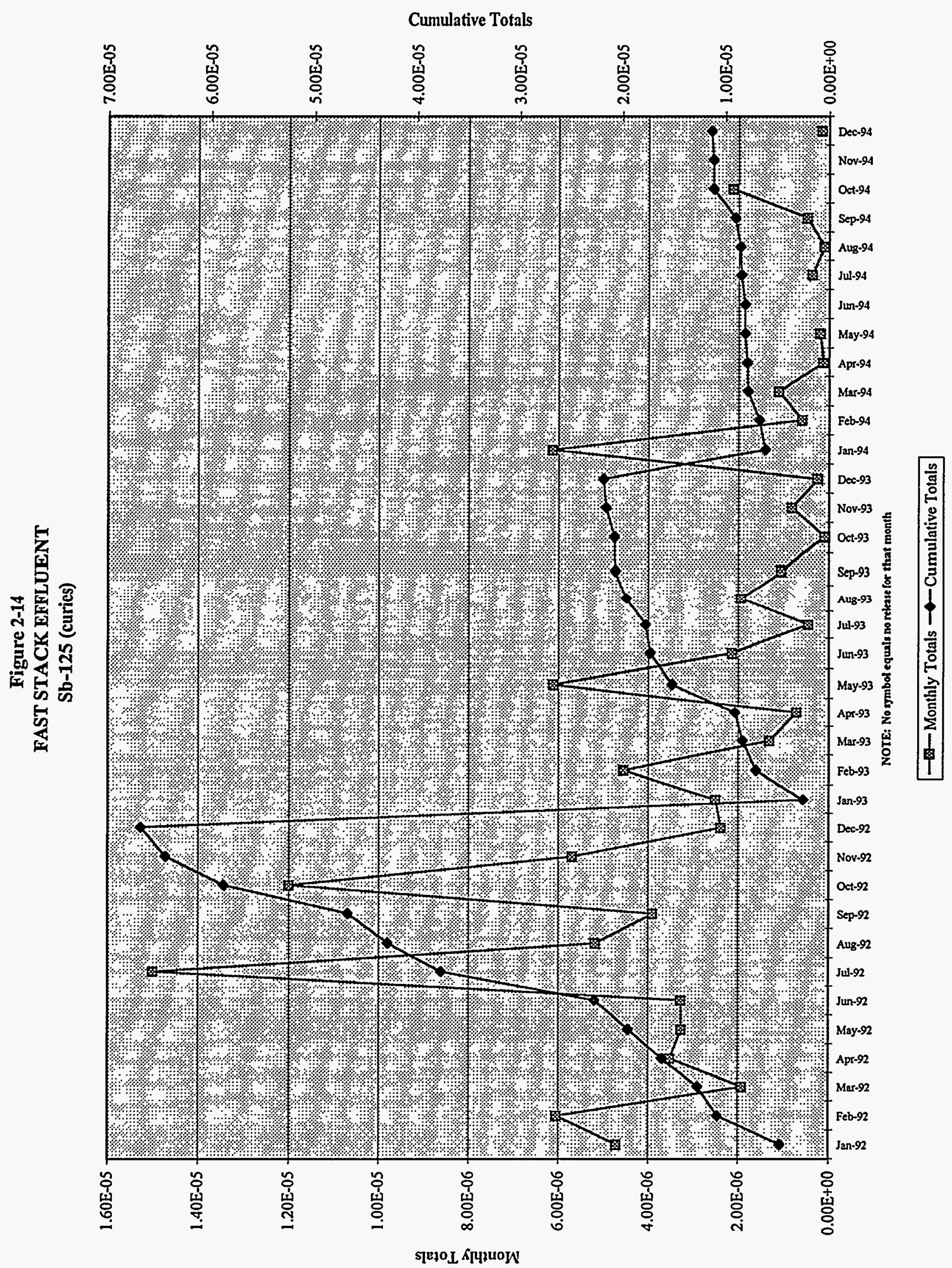




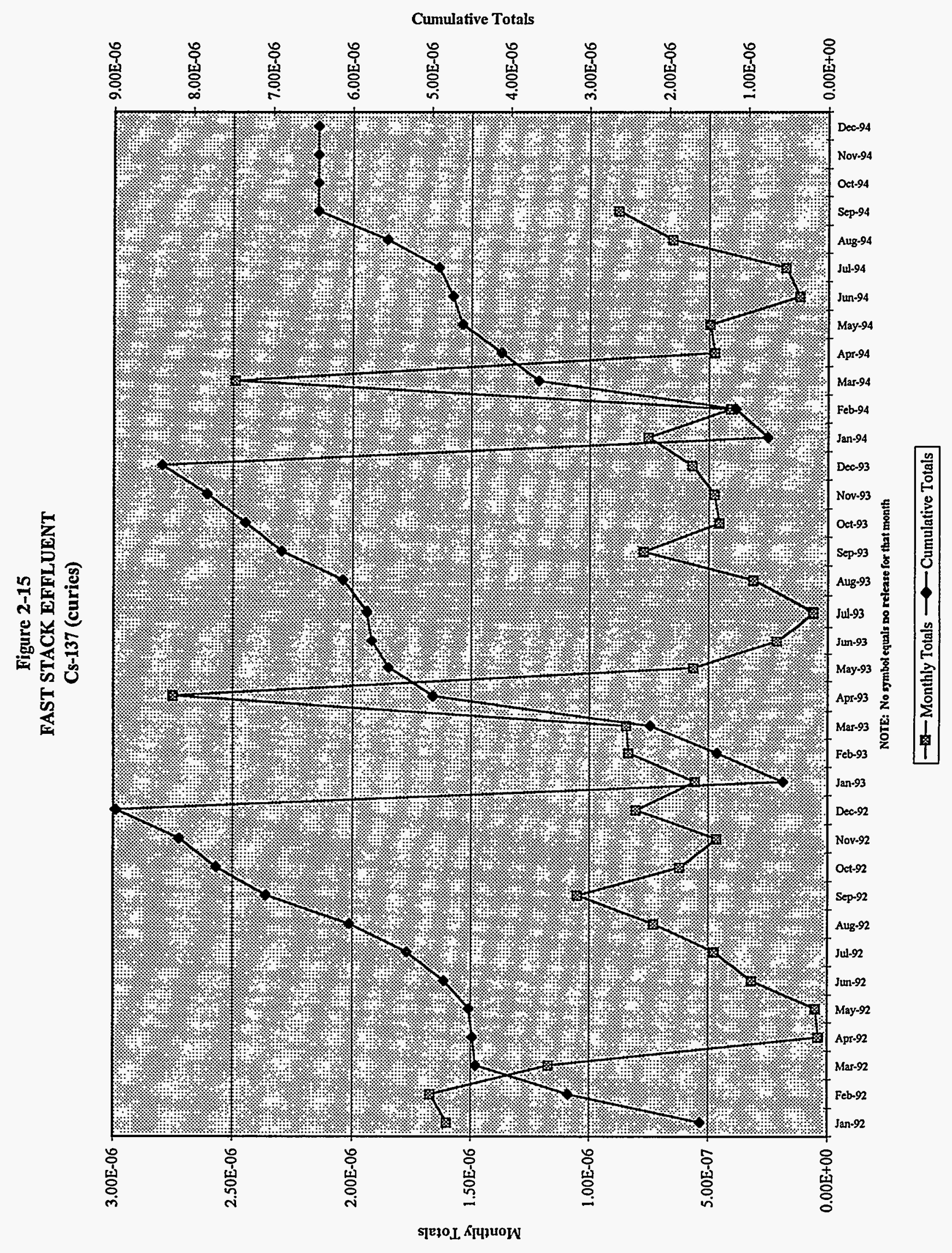




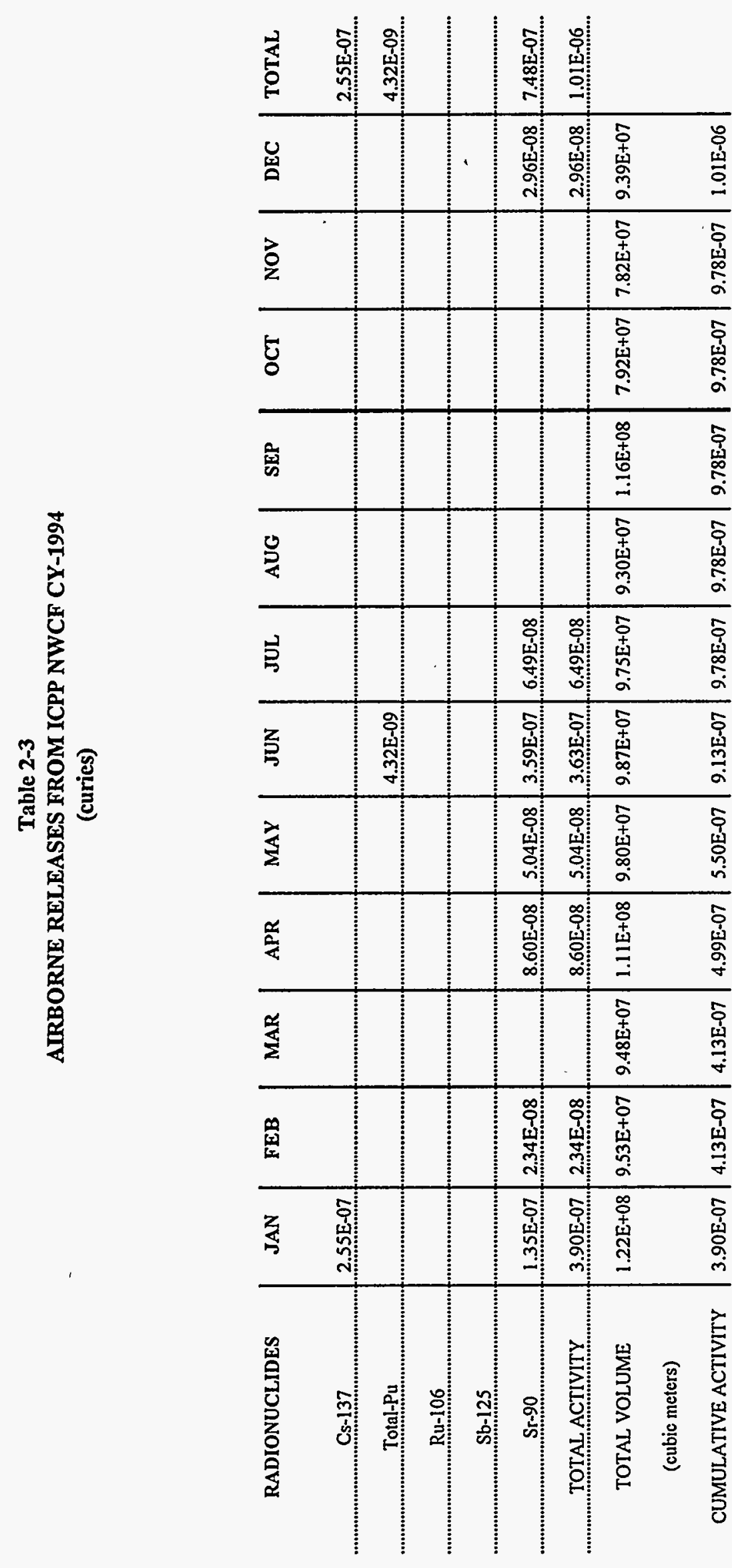

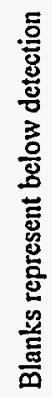




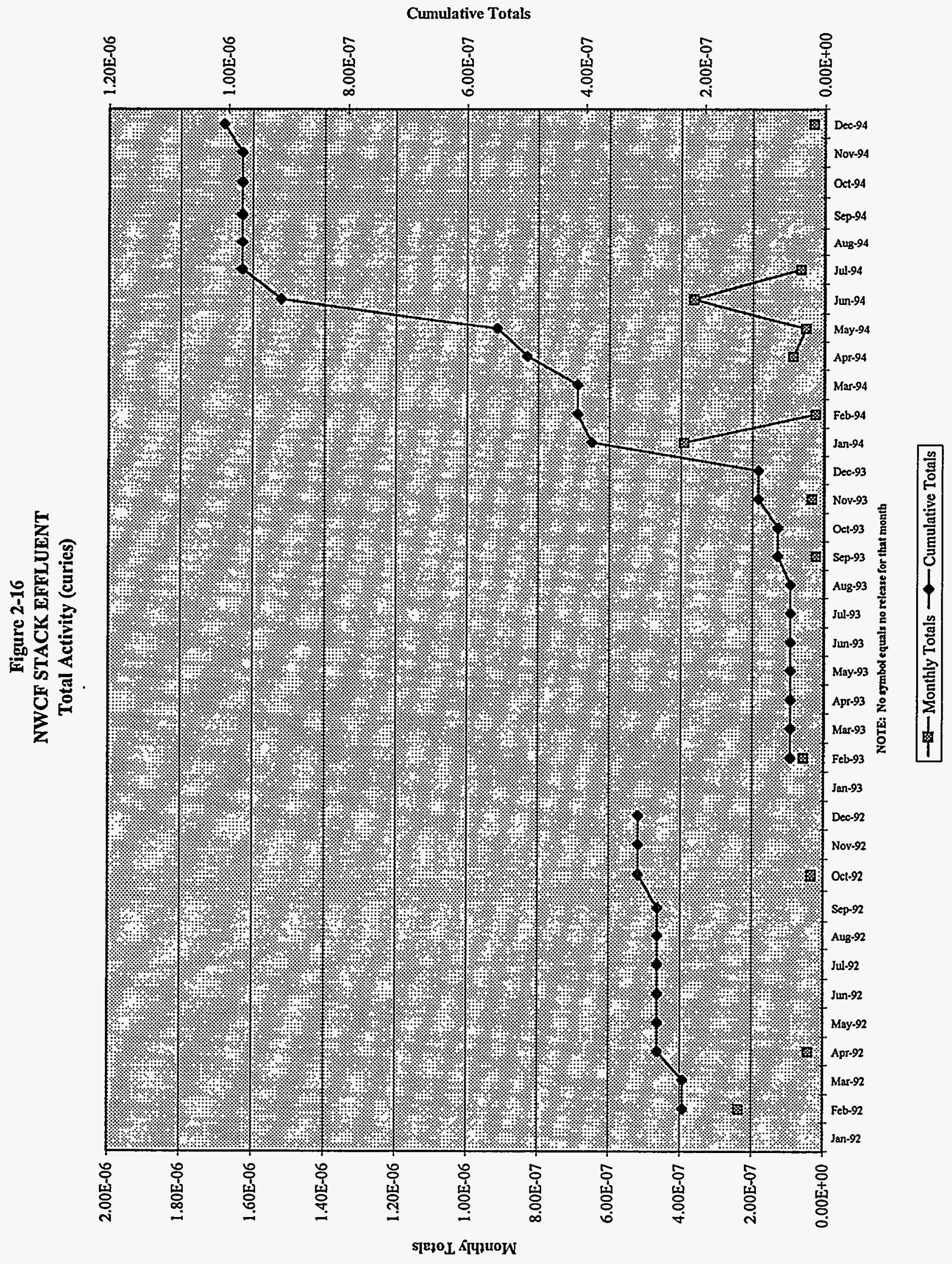




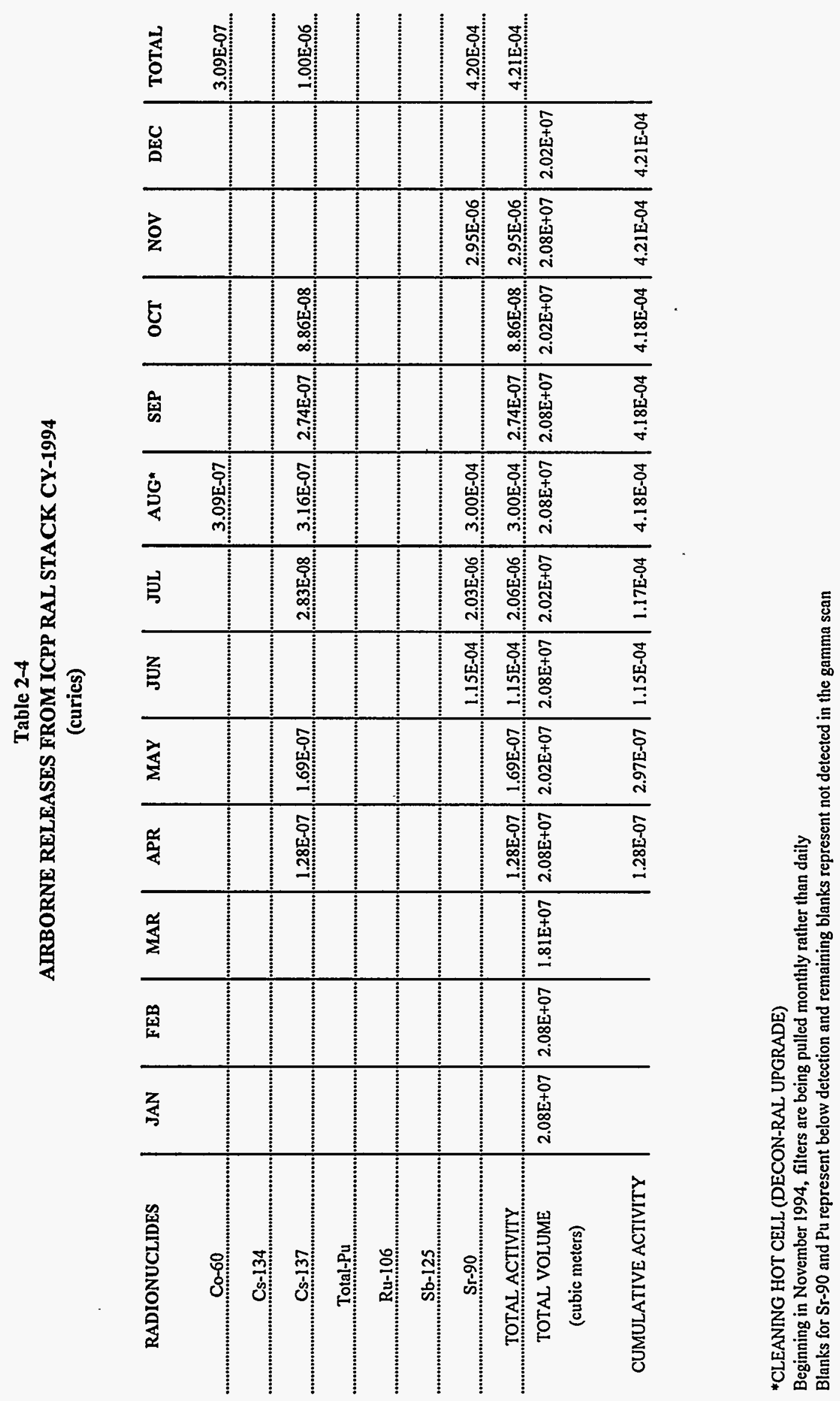




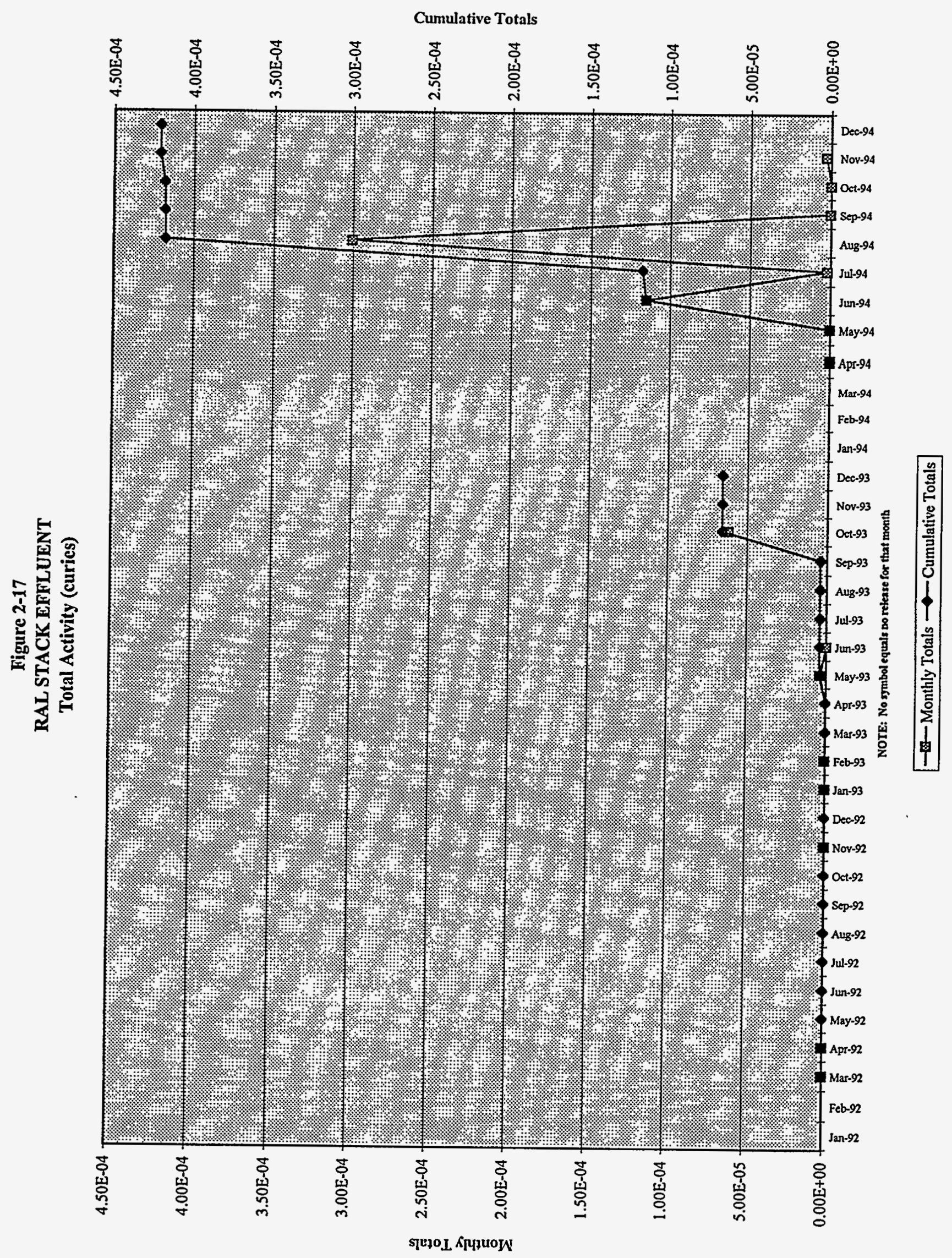


Table 2-5

CY-1994

COAL FIRED STEAM GENERATOR FACILITY

\begin{tabular}{|c|c|c|c|c|c|c|c|c|c|c|c|c|c|}
\hline & JAN & FEB & MAR & APR & MAY & JUN* & JUL & AUG & SEP & OCT & NOV & DEC & $\begin{array}{l}\text { EMISSION } \\
\text { LIMITATIONS }\end{array}$ \\
\hline COAL BURNED (TONS) & 1260 & 827 & & & & 1035 & 873 & 1778 & 602 & & 856 & 1492 & N/A \\
\hline $\begin{array}{l}\text { CUMULATIVE COAL BURNED } \\
\text { (TONS) }\end{array}$ & 1260 & 2087 & 2087 & 2087 & 2087 & 3122 & 3995 & 5773 & 6375 & 6375 & 7231 & 8723 & N/A \\
\hline MM/Btu/\#Burned & 0.012798 & 0.012798 & & & & 0.012535 & 0.012535 & 0.012535 & 0.012535 & & 0.012535 & 0.012535 & N/A \\
\hline$\%$ Sulfur & 0.41 & 0.41 & & & & 0.37 & 0.37 & 0.37 & 0.37 & & 0.37 & 0.37 & N/A \\
\hline \#NOX/MM/Btu & 0.39 & 0.39 & & & & 0.38 & 0.42 & 0.43 & 0.48 & & 0.38 & 0.4 & SEE FOOTNOTE \\
\hline \#SO2/MM/Btu & 0.06 & 0.04 & & & & 0.02 & 0.05 & 0.06 & 0.07 & & 0.02 & 0.06 & 0.6 \\
\hline $\begin{array}{c}\text { Permit Steam Flow Range } A \text { or } \\
\text { B }\end{array}$ & $\mathrm{B}$ & $\mathrm{B}$ & & & & $\mathrm{B}$ & A & A & A & & $\mathrm{B}$ & B & SEE FOOTNOTE \\
\hline$\%$ SO2 Removed & 91 & 93 & & & & 95.8 & 91 & 89.6 & 87.6 & & 96.2 & 90.4 & 70\% OR GREATER \\
\hline$\%$ Opacity & 0 & 1 & & & & 2 & 2 & 3 & 2 & & 2 & 3 & \\
\hline${ }^{*}$ Carbon Monoxlde (CO) lbs/hr & & & & & & 34.8 & 19.3 & 21.5 & 30 & & 30.4 & 35.55 & 148.5 \\
\hline Carbon Monoxide $(\mathrm{CO})$ tons & & & & & & 7.15 & 6.98 & 16 & 5.42 & & 7.45 & 12.3 & \\
\hline $\begin{array}{c}\text { Carbon Monoxide (CO) TONS } \\
\text { CUMULATIVE }\end{array}$ & & & & & & 7.15 & 14.13 & 30.13 & 35.55 & 35.55 & 43 & 55.3 & 650.4 \\
\hline
\end{tabular}

Opacity $=<20 \%$

Coal Bumed (lons) $=$ N/A

MM/Btu burned = NA

*CO started being reported to Environmental Characterization in June, due to permit modification

$\%$ Sulfur $=$ N/A

Nitrogen oxide (lbs. NOx/MM/Btu) emissions shall not exceed an average of 0.5 pounds per million Btu (Range B) for steam flow greater or equal to $35000 \mathrm{lbs} / \mathrm{hr}$.

Nitrogen oxide (lbs. NOx/MM/Btu) emissions shall not exceed an average of 0.7 pounds per million Btu (Range A) for steam flow less than 35000 lbshts.

Sulfur dioxide (lbs. SO2MM/Btu) emissions shall not exceed an average of 0.6 pounds per million Btu of fuel input, averaged over a 24 hour period.

$\% \mathrm{SO} 2$ removal $=70 \%$ or greater and shall be calculated as an average over a 30 day period.

Steam flow $=$ N/A (Range $B=$ steam load equal to or greater than 35000 pounds per hour and Range $A=$ steam load less than 35000 pounds per hour)

Carbon monoxide (CO) emissions for the boilers shall not exceed an average of $148.5 \mathrm{lbs} / \mathrm{hr}$ averaged over a 30 day period. 


\section{LIQUID MONITORING}

\section{INTRODUCTION}

Liquid monitoring discussed in this report includes: 1) Service Waste System; 2) Percolation Ponds 1 \& 2; 3) Sewage Treatment Plant; and 4) Production and Potable Water We11s. Quality Assurance objectives for measurement data and Taboratory performance are 1isted in both the Quality Assurance Project P1an for the Analysis of Environmental Samples by the LITCO Ana7ytical Chemistry Section and the Special Technologies Quality Assurance Project Plans for Work Subject to EPA QAMS-005/80.

\section{LIQUID RELEASES TO THE ENVIRONMENT}

\subsection{Service Waste System}

Liquid waste streams are generated from all areas of the ICPP. The waste streams vary in volume. Waste streams are disposed of through the Service Waste System. The Liquid Effluent Treatment and Disposal (LET\&D) Facility began operation on January 1, 1993. PEW condensates which previously were discharged to Service Waste are now treated in the LET\&D facility.

Isotopic radionuclide and inorganic chemical release data for the Service Waste System for each month and year totals are presented in Table 3-1 and 3-2. Table 3-3 lists the monthly DCG release ratios respectively for individual radionuclides. DCGs are not release limits, but rather are screening values for considering Best Available Technology (BAT) for discharges and dose estimates.

The radionuclides reported are those that have been found in the past. Listed radionuclides that do not have values shown were not observed during the reporting month or were below detection 1 imits. Figure 3-1 depicts the total monthly activity released to the active Percolation Pond at ICPP.

Figure 3-2 depicts total plutonium and figure 3-3 depicts total uranium found in the service waste stream. The quantity of plutonium and uranium released to the Pond remained relatively constant during 1994. Figures 3-4 through 3-7 present trend information for select radionuclides in the Service Waste.

The ratio is calculated by dividing the detected radionuclide concentration by the established limit. Governmental regulations state that a corrected total ratio of 1.0 equals allowable radionuclide concentrations. The ICPP did not approach the total allowable release at any time during 1994. The ICPP did not exceed a ratio of 1.0 during any month in 1994 . 
Table 3-1

LIQUID RELEASES FROM ICPP SERVICE WASTE CY-1994

(curies)

\begin{tabular}{|c|c|c|c|c|c|c|c|c|c|c|c|c|c|}
\hline RADIONUCLIDES & JAN & FEB & MAR & APR & MAY & JUN & JUL & AUG & SEP & OCT & NOV & DEC & TOTAL \\
\hline Co-60 & & $3.78 \mathrm{E}-05$ & $3.89 \mathrm{E}-05$ & & & & & & & & $3.50 \mathrm{E}-05$ & & $1.12 \mathrm{E}-04$ \\
\hline \multicolumn{14}{|l|}{ Cs-134. } \\
\hline Cs-137. & $6.93 E-05$ & $4.68 \mathrm{E}-05$ & $1.57 \mathrm{E}-05$ & $8.25 \mathrm{E}-05$ & $642 E-05$ & $7.66 \mathrm{E}-05$ & $8.32 \mathrm{E}-05$ & $1.42 \mathrm{E}-05$ & & & & & 4.53E-04 \\
\hline \multicolumn{14}{|l|}{ 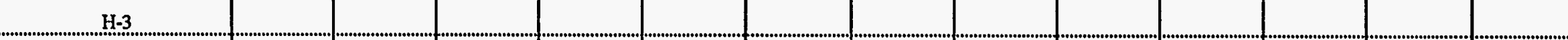 } \\
\hline \multicolumn{14}{|l|}{. } \\
\hline Pu-238 & & & & & & & & & & $5.79 \mathrm{E}-06$ & ...73E-06 & & $8.52 E-06$. \\
\hline \multicolumn{14}{|l|}{ Pu-239 } \\
\hline \multicolumn{14}{|l|}{ Pu=241. } \\
\hline \multicolumn{14}{|l|}{ Ru-106 } \\
\hline Sb-125. & & & & & & & $.4 .24 \mathrm{E}-05$ & & & & & & $4.24 \mathrm{E}-05$ \\
\hline Sr-90 & 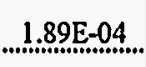 & & & 1.07E-04 & & & & & $3.81 \mathrm{E}-04$ & & & & $6.77 \mathrm{E}-04$ \\
\hline *U-234. & .....78E-04 & $2.47 \mathrm{E}-04$ & $3.33 E-04$ & $3.00 E-04$ & 2.95E-04. & . $2.42 E-04$ & $2.00 E-04$ & 2.29E-04 & 2.44E-04. & $2.40 \mathrm{E}-04$ & $2.43 E-04$. & ...23E-04. & $3.17 \mathrm{E}-03$ \\
\hline U-235............ & & $4.63 \mathrm{E}-06$ & $1.66 \mathrm{E}-05$ & $7.50 \mathrm{E}-06$ & $5.52 E-06$. & 7.57E-06. & & 4.01E-06. & $7.62 \mathrm{E}-06$ & $4.52 E-06$. & & 7.27E-06. & $6.52 E-05$. \\
\hline U-238 & & $1.23 E-04$ & $1.46 \mathrm{E}-04$ & $1.50 \mathrm{E}-04$ & 1. & $1.21 \mathrm{E}-04$ & 1.07E-04 & 1.09E-04. & $1.11 \mathrm{E}-04$ & 1.16E-04 & $1.17 \mathrm{E}-04$ & $1.14 E-04$ & $1.36 \mathrm{E}-03$ \\
\hline TOTAL ACTIVITY & $6.36 \mathrm{E}-04$ & $4.59 \mathrm{E}-04$ & $5.50 \mathrm{E}-04$ & $6.47 E-04$ & $5.12 E-04$ & $4.47 E-04$ & $.3 .33 E-04$ & $3.56 \mathrm{E}-04$ & 7.44E-04. & $3.66 \mathrm{E}-04$ & $3.98 \mathrm{E}-04$ & $3.44 \mathrm{E}-04$ & $5.89 \mathrm{E}-03$ \\
\hline $\begin{array}{l}\text { TOTAL VOLUME } \\
\quad \text { (liters) }\end{array}$ & $2.10 \mathrm{E}+08$ & $1.54 \mathrm{E}+08$ & $2.08 \mathrm{E}+08$ & $1.88 \mathrm{E}+08$ & $1.84 \mathrm{E}+08$ & $1.51 E+08$ & $1.33 E+08$ & $1.43 \mathrm{E}+08$ & $1.52 \mathrm{E}+08$ & $1.41 \mathrm{E}+08$ & $1.52 \mathrm{E}+08$ & $1.48 \mathrm{E}+08$ & \\
\hline CUMULATIVE ACTIVITY & $6.36 \mathrm{E}-04$ & $1.10 \mathrm{E}-03$ & $1.65 \mathrm{E}-03$ & $2.29 \mathrm{E}-03$ & $2.80 \mathrm{E}-03$ & $3.25 \mathrm{E}-03$ & $3.68 \mathrm{E}-03$ & $4.04 E-03$ & $4.78 \mathrm{E}-03$ & $5.15 \mathrm{E}-03$ & $5.55 \mathrm{E}-03$ & $5.89 \mathrm{E}-03$ & \\
\hline
\end{tabular}

-NOTE: JANUARY URANIUM IS ACTUALLY U.TOTAL DUE TO CLASSIFICATION.

Blanks for H-3, C-14, St-90, I-129, U-234, U-235, U-238, Pu-238, Pu-239 and Pu-241 indicate below delection limit and remaining radionuclides represent not detected in gamma scan 
Table 3-2

ICPP SERVICE WASTE CY-1994

(mg/L)

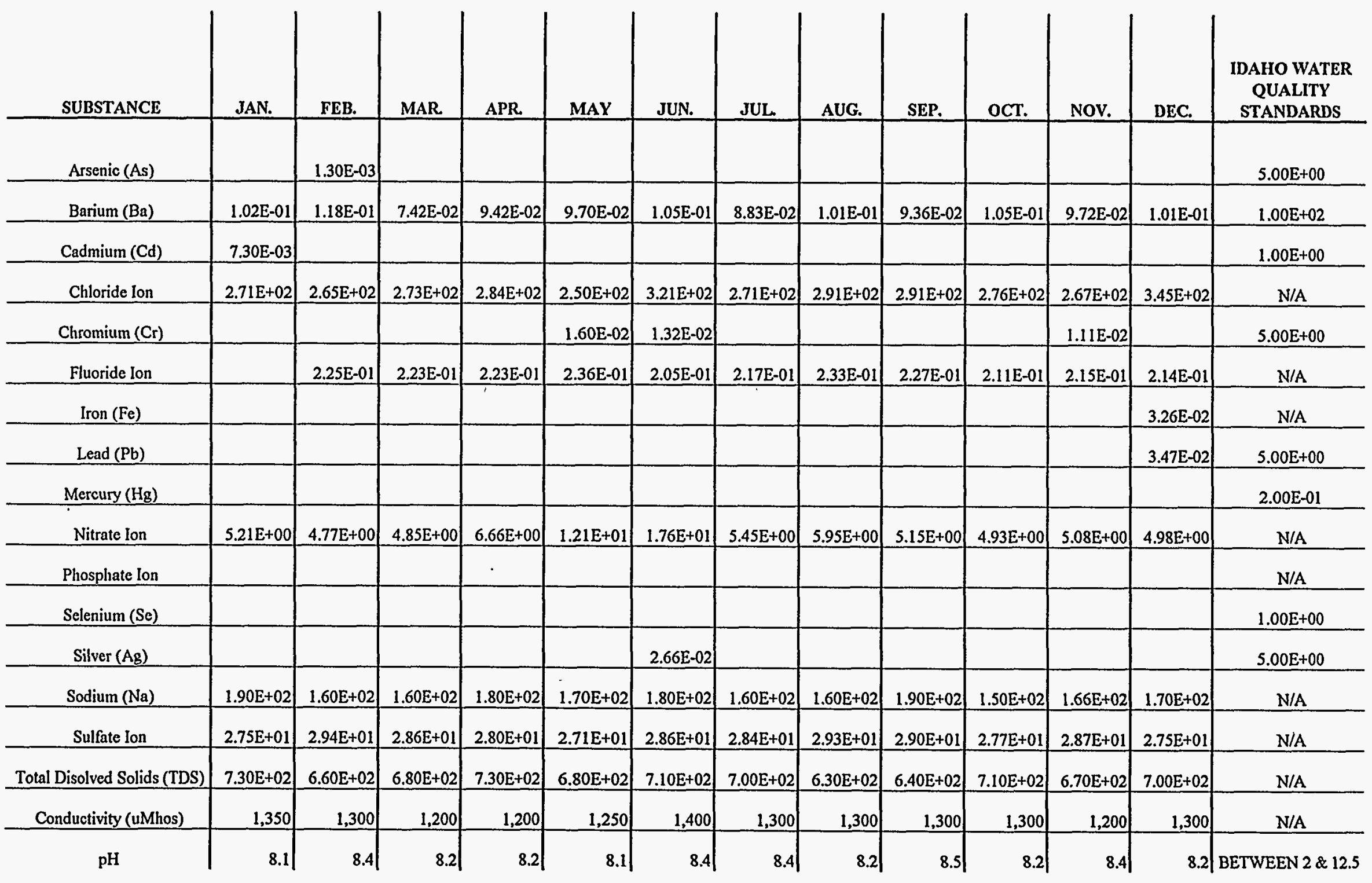




\begin{tabular}{|c|c|c|c|c|c|c|c|c|c|c|c|c|}
\hline RADIONUCLIDES & JAN & FEB & MAR & APR & MAY & JN & JUL & AUG & SEP & OCT & Nov & DEC \\
\hline C-14 & & & & & & & & & & & & \\
\hline $\mathrm{C}_{0}-60$ & & $3.60 \mathrm{E}-05$ & $3.74 \mathrm{E}-05$ & & & & & & & & 4.61E-05 & \\
\hline$C_{s-134}$ & & & & & & & & & & & & \\
\hline Cs-137 & $1.10 \mathrm{E}-04$ & $1.01 E-04$ & $2.52 \mathrm{E}-05$ & $1.46 \mathrm{E}-04$ & $1.16 \mathrm{E}-04$ & $1.69 \mathrm{E}-04$ & 2.09E-04 & 3.31E-05 & & & & \\
\hline $\mathrm{H}-3$ & & & & & & & & & & & & \\
\hline I-129 & & & & & & & & & & & & \\
\hline Pu-238 & & & & & & & & & & $1.03 \mathrm{E}-03$ & 4.49E-04 & \\
\hline Pu-239 & & & & & & & & & & & & \\
\hline Pu-241 & & & & & & & & & & & & \\
\hline $\mathrm{Ru}-106$ & & & & & & & & & & & & \\
\hline Sb-125 & & & & & & & $6.38 \mathrm{E}-06$ & & & & & \\
\hline Sr -90 & $9.00 E-04$ & & & $5.69 \mathrm{E}-04$ & & & & & $2.51 \mathrm{E}-03$ & & & \\
\hline U-234 & $3.60 \mathrm{E}-02$ & $3.21 \mathrm{E}-03$ & $3.20 \mathrm{E}-03$ & $3.19 \mathrm{E}-03$ & $3.21 \mathrm{E}-03$ & $3.21 \mathrm{E}-03$ & $3.01 \mathrm{E}-03$ & $3.20 \mathrm{E}-03$ & $3.21 \mathrm{E}-03$ & $3.40 \mathrm{E}-03$ & $3.20 \mathrm{E}-03$ & $3.01 \mathrm{E}-03$ \\
\hline U.235 & & $5.01 E-05$ & 1.33E-04 & $6.65 \mathrm{E}-05$ & $5.00 \mathrm{E}-05$ & $8.36 \mathrm{E}-05$ & & 4.67E-05 & $8.36 \mathrm{E}-05$ & $5.34 \mathrm{E}-05$ & & $8.19 \mathrm{E}-05$ \\
\hline U-238 & & $1.33 \mathrm{E}-03$ & $1.17 \mathrm{E}-03$ & $1.33 \mathrm{E}-03$ & $1.33 \mathrm{E}-03$ & $1.34 \mathrm{E}-03$ & $1.34 \mathrm{E}-03$ & $1.27 \mathrm{E}-03$ & $1.22 \mathrm{E}-03$ & $1.37 \mathrm{E}-03$ & $1.28 \mathrm{E}-03$ & $1.28 \mathrm{E}-03$ \\
\hline
\end{tabular}




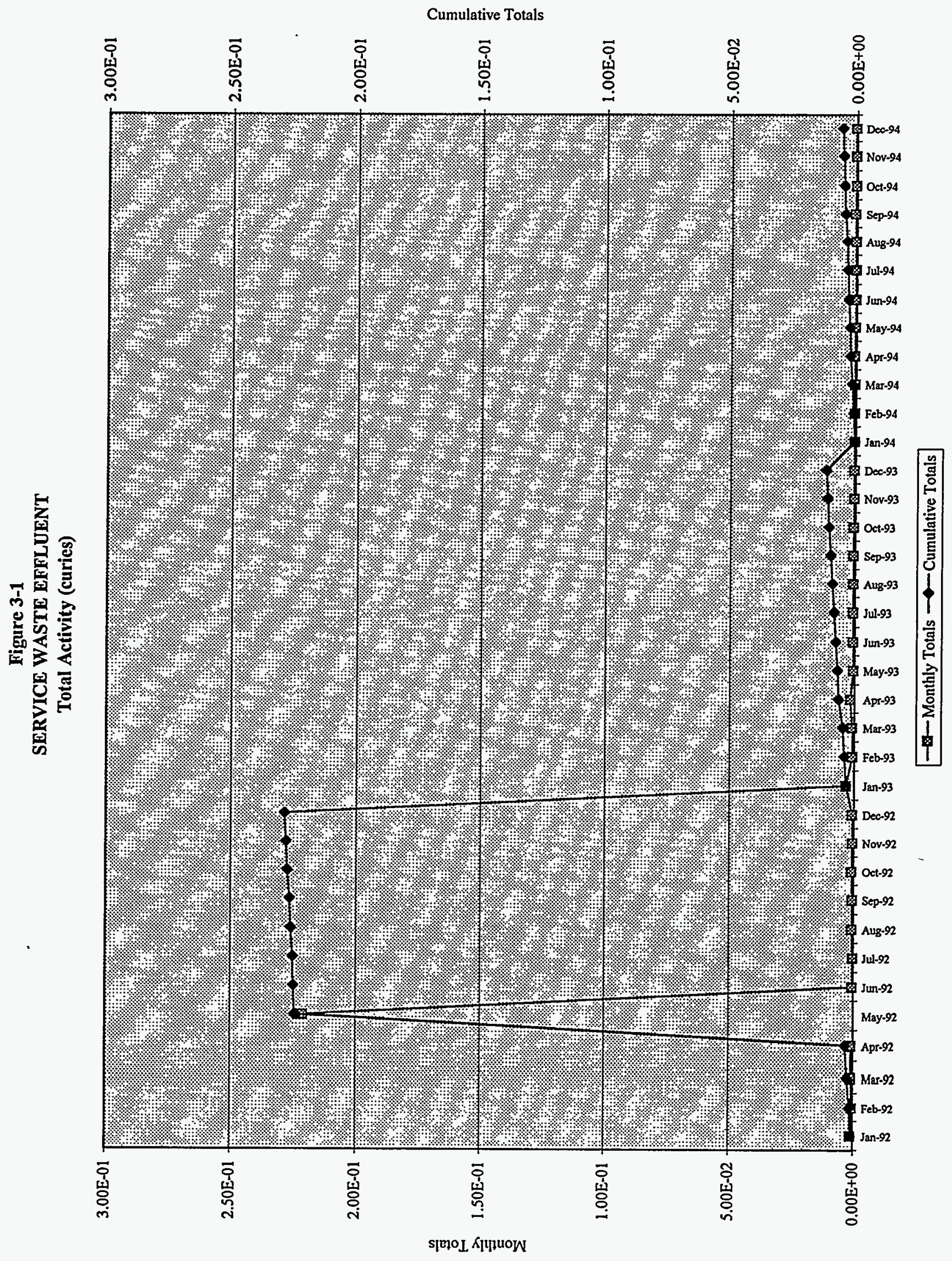


Figure 3-2

SERVICE WASTE EFFLUENT

Total-Pu (curies)

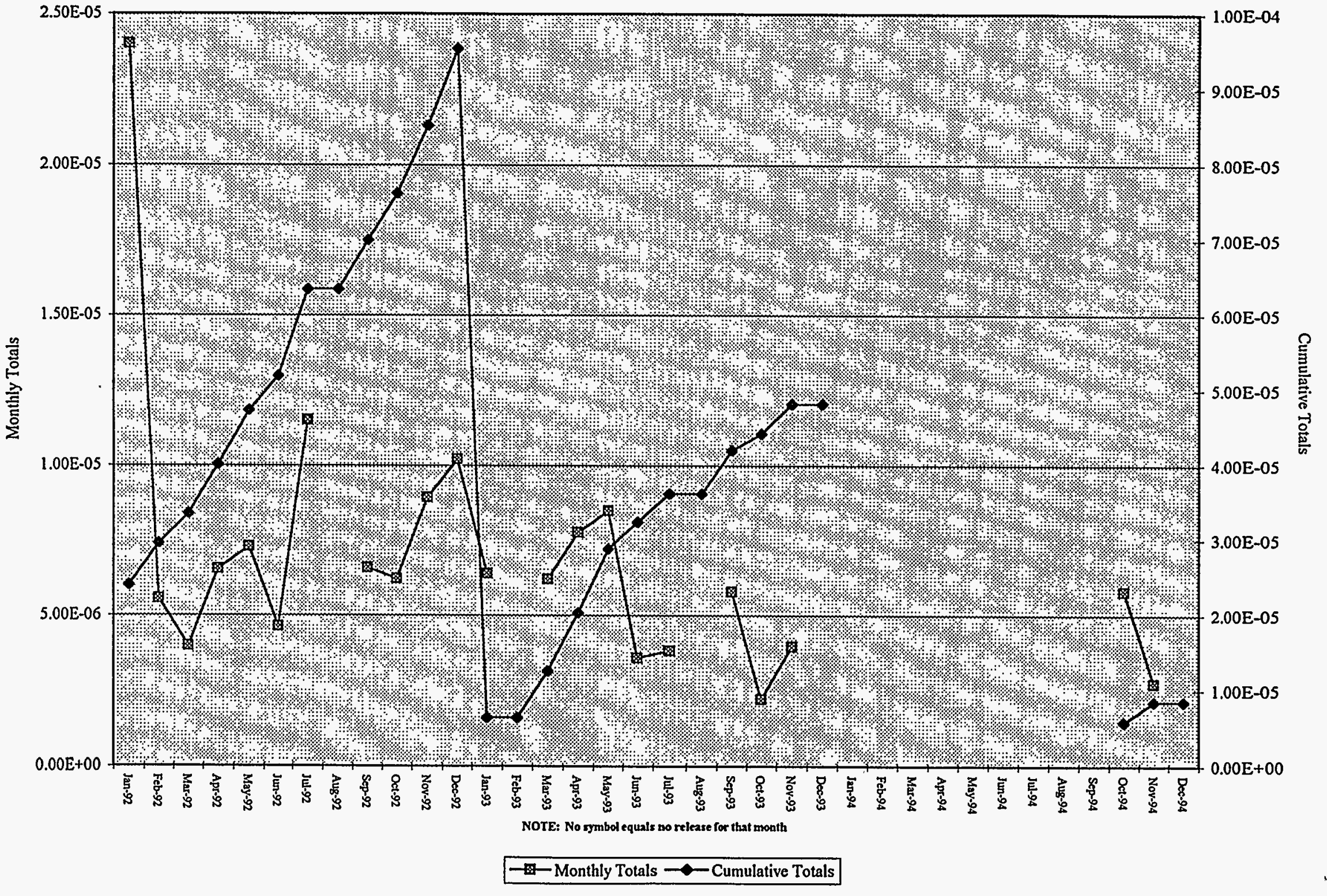




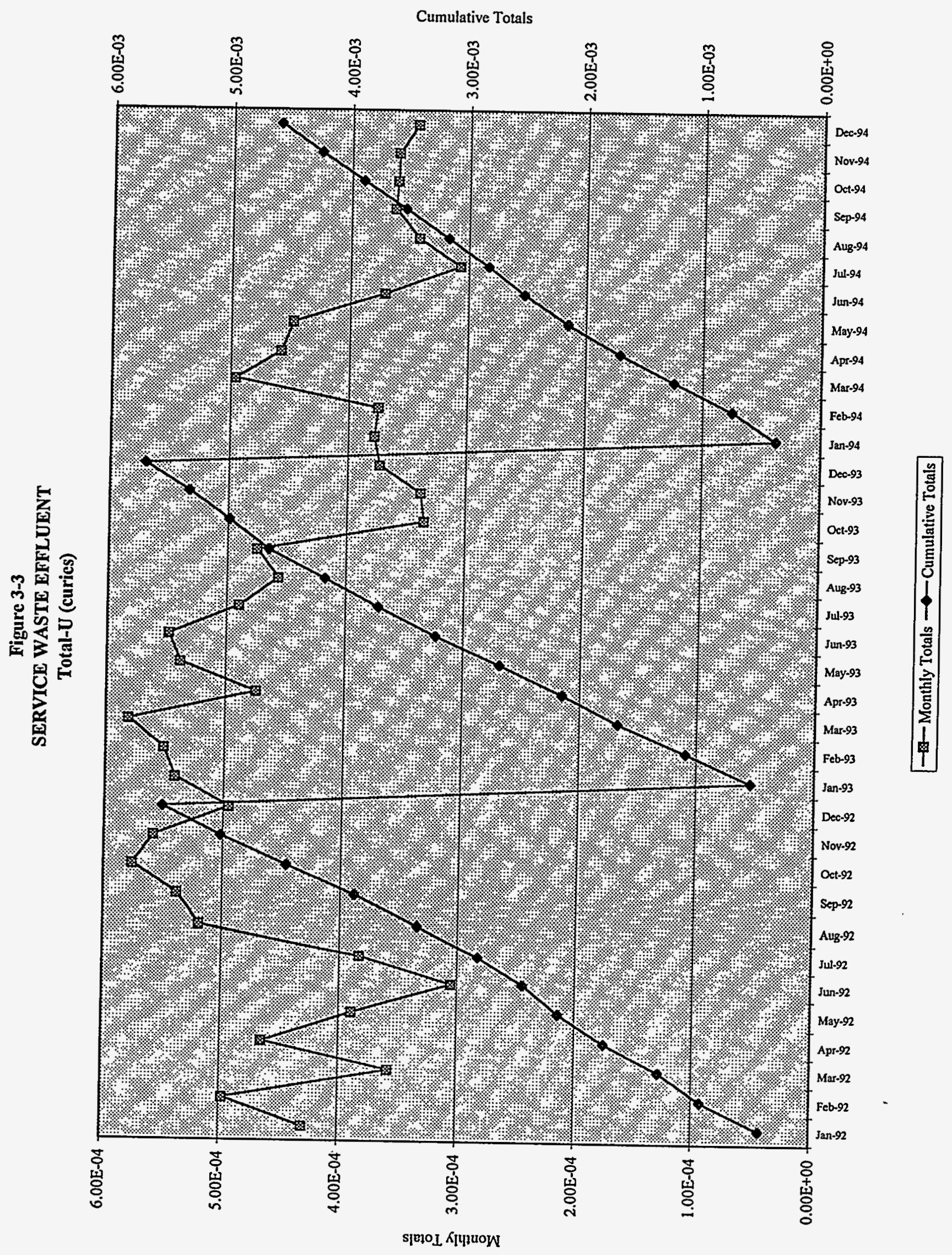


Figure 3-4

SERVICE WASTE EFELUENT

H-3 (curies)

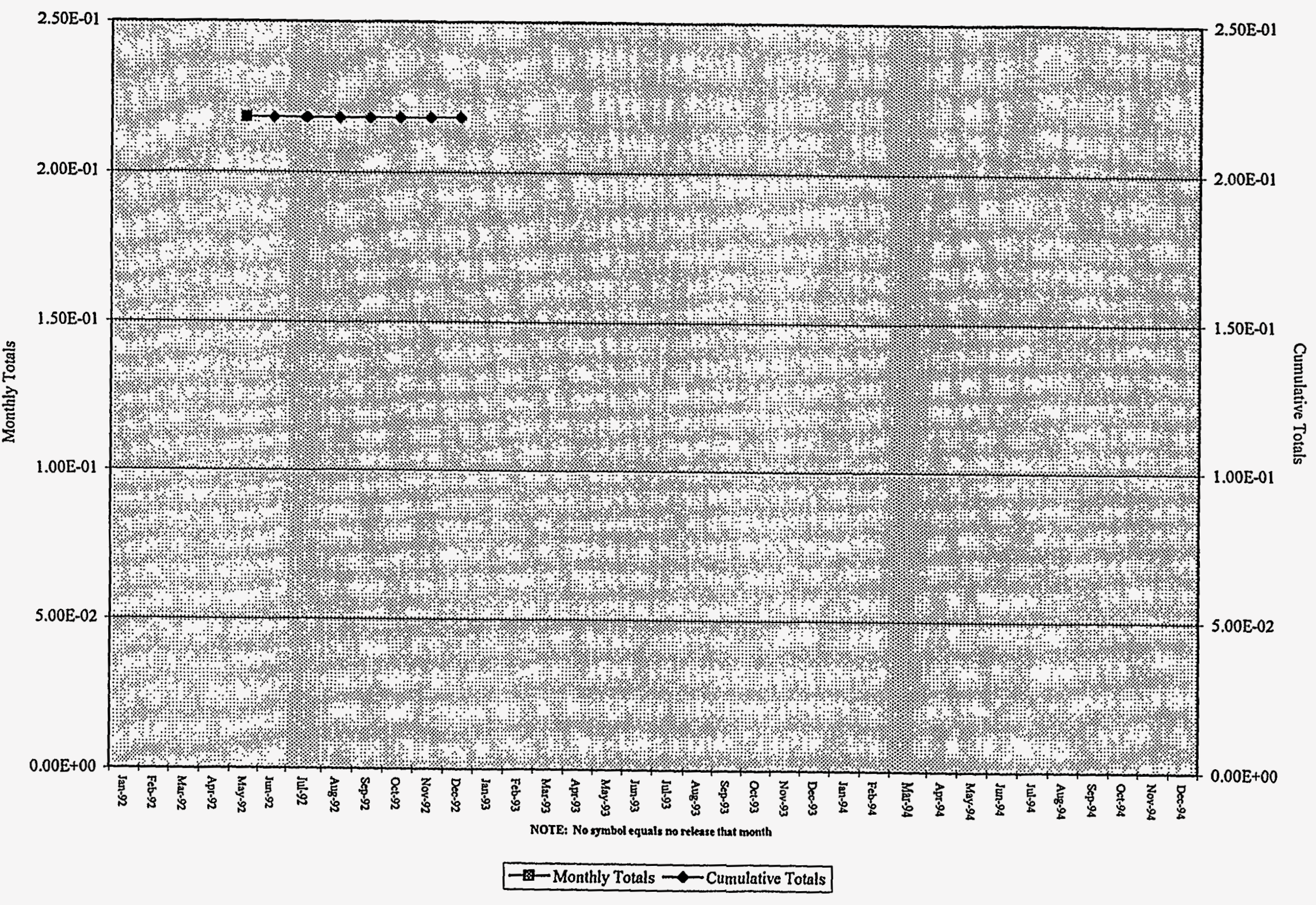




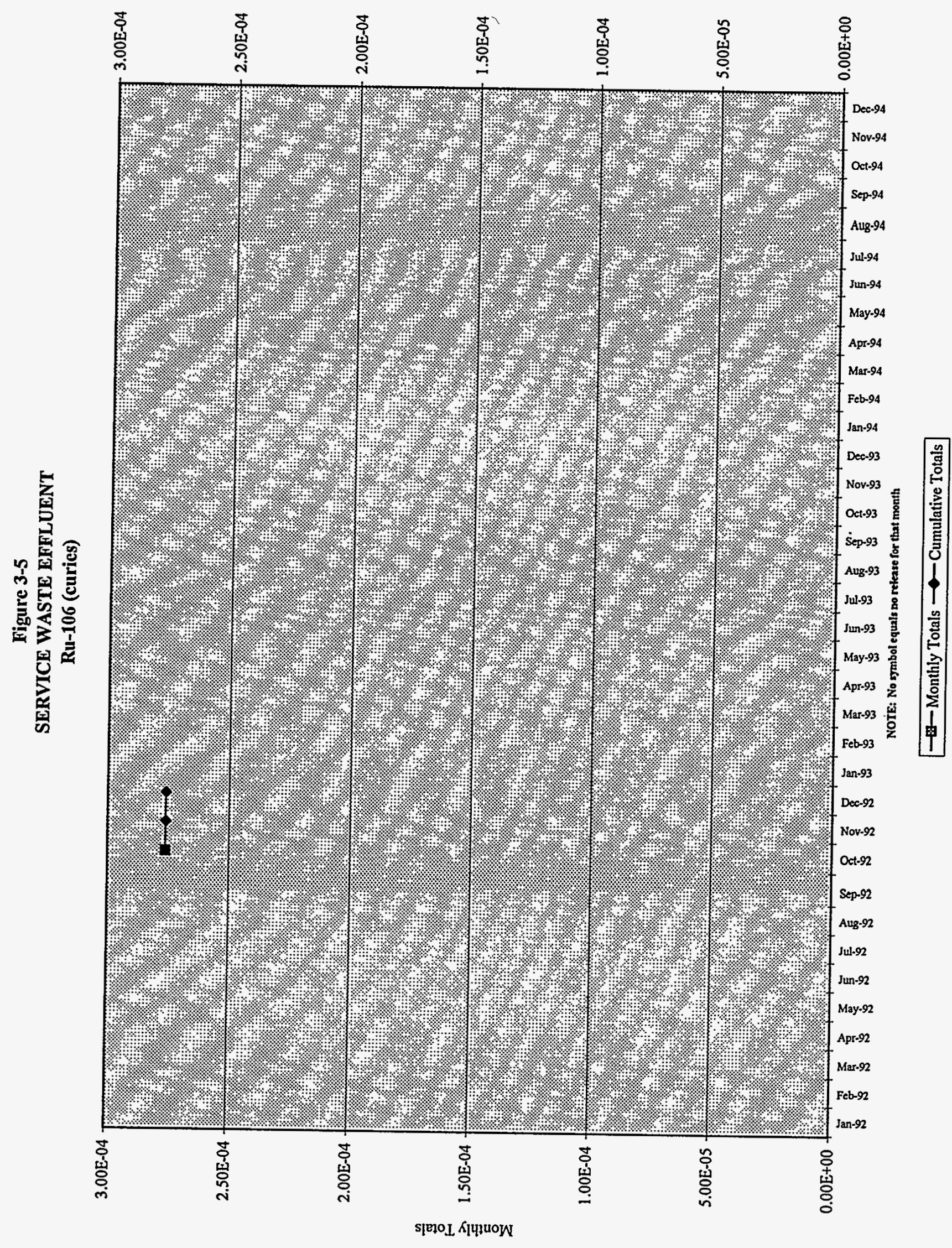


Figure 3-6

SERVICE WASTE EFFLUENT

\section{Sr-90 (curies)}

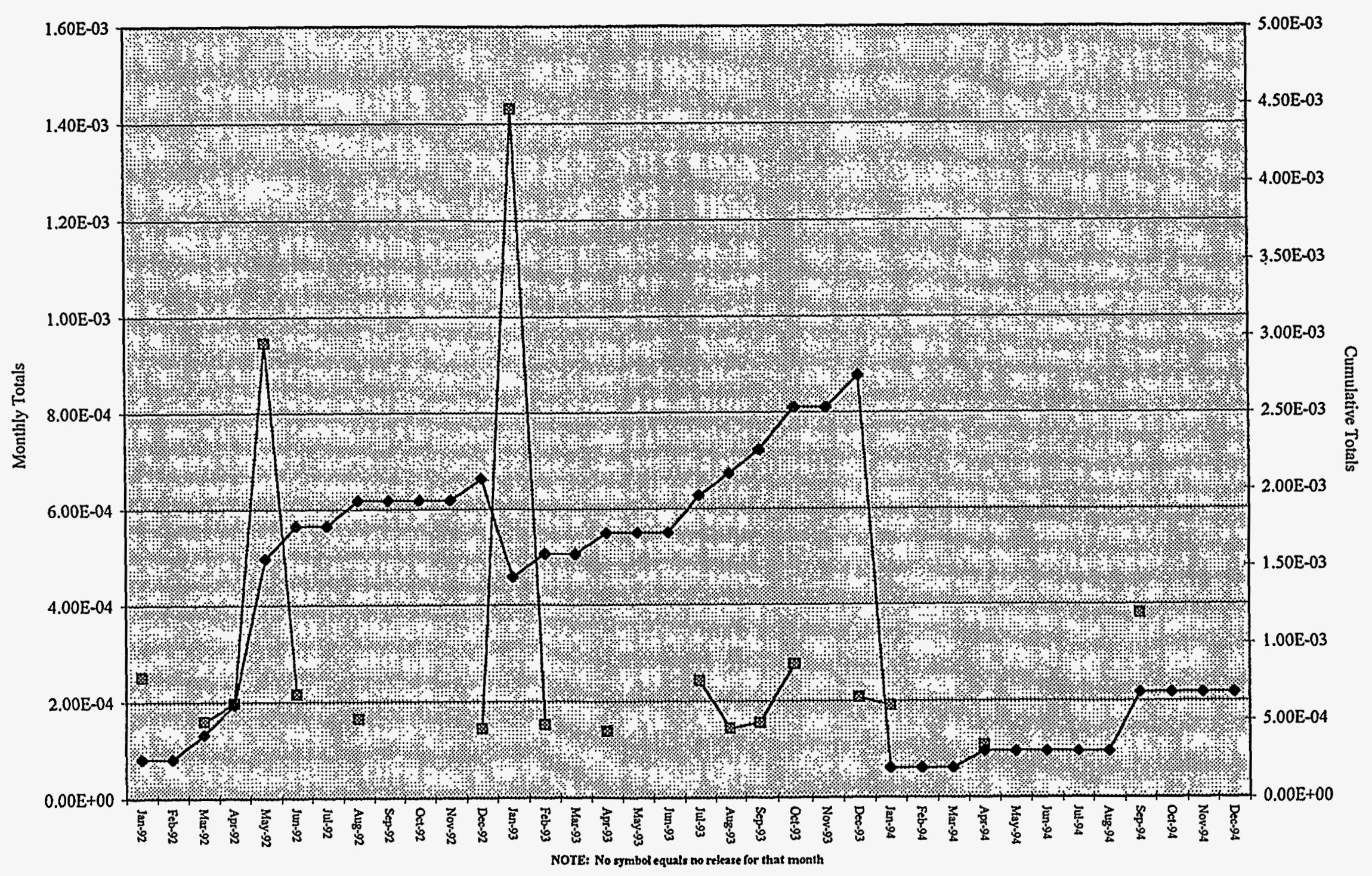

$-6-$ Monthly Totals $\rightarrow-$ Cumulative Totals 


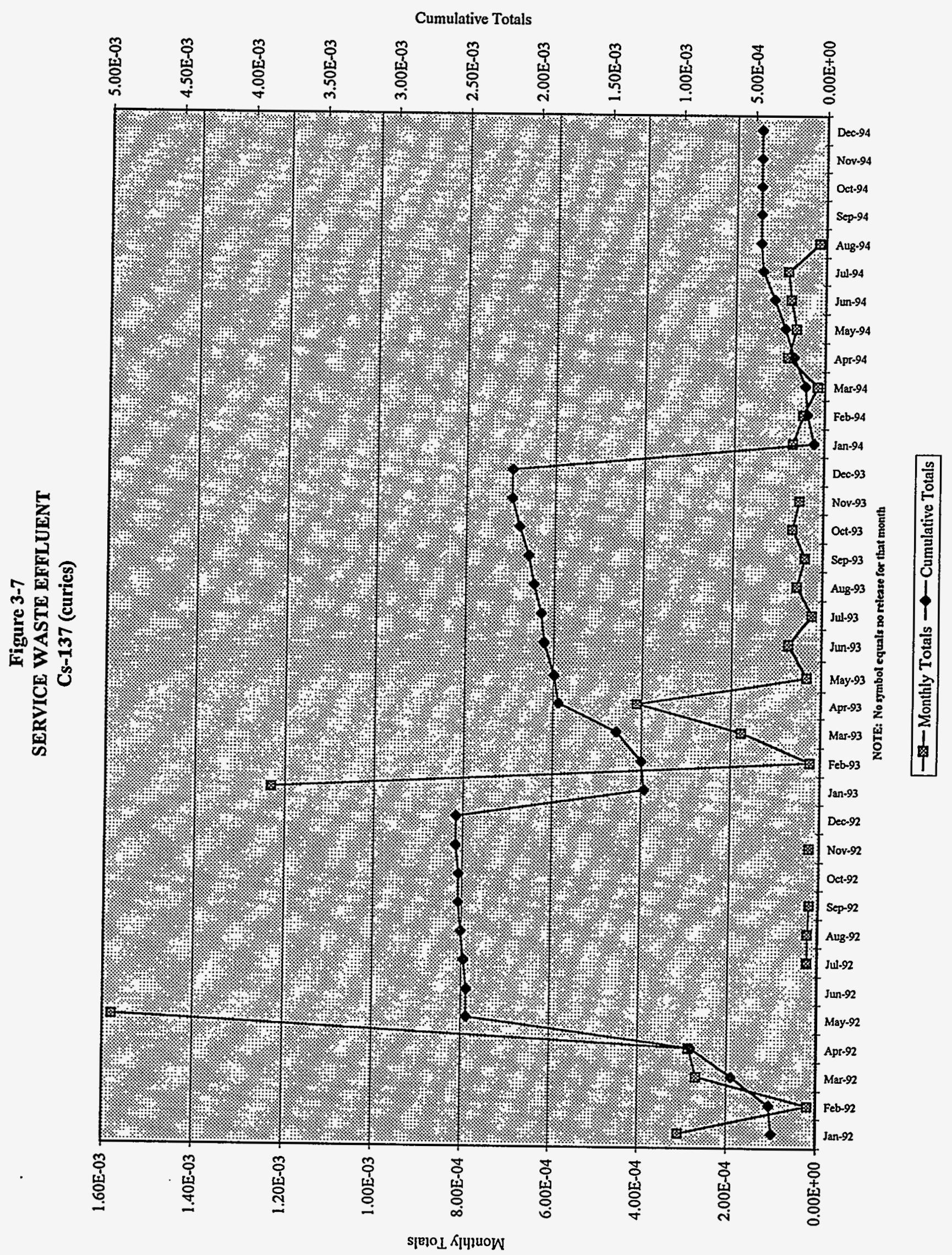




\subsection{Production and Potable Water Wells}

There are two production wells and one potable water well for influent at the ICPP. The production wells are operated alternately. Grab samples are collected monthly from the operating wells. Radiological analysis of the well water is done by the AccuLabs Research, Inc.

Nonradiological analyses for arsenic, barium, cadmium, chloride, chromium, lead, mercury, nitrate, selenium, and silver are performed monthly by the Analytical Chemistry group. Periodically, grab samples are analyzed for the following organic contaminants: total organic carbon; Endrin; Lindane; Methoxychlor; Toxaphene; 2-4-D; and 2,4,5-TP Silvex.

Tables 3-4 and 3-5 list the results of the analyses performed on the Production and Potable Water Wells. All results indicate that the ICPP well waters are below all applicable regulatory standards for trace metals and organics. The Environmental Safety \& Health department collects monthly samples of the wells to perform analyses for tritium and strontium, and sends the samples off-site to Acculab in Colorado.

\subsection{Sewage Treatment Plant}

Domestic waste water at the ICPP is pumped to the Waste Water Treatment Facility which is located outside the security fence. LITCO Power Plant Services is responsible for the operation and maintenance of the Waste Water Treatment Facility. LITCO

Environmental Protection department takes monthly grab samples for radionuclides. The samples are analyzed for gross alpha, gross beta and gamma. The LITCO Environmental Safety \& Health Department monitors the operation and performance of the domestic Waste Water Treatment Plant. Table 3-6 Tists the month7y Biological Oxygen Demand (BOD), Dissolved 0xygen (DO) and $\mathrm{pH}$ for 1994. Table 3-6 al so lists the monthly strontium, quarterly plutonium (total).

Monthly influent (raw) and effluent (final) Biological 0xygen Demand (BOD) concentrations are shown in Figure 3-8. The difference in concentrations between influent $B O D$ and effluent $B O D$ represents the treatment efficiency.

Since the facility has been operational, treatment efficiency has met design criteria (80\%) except during algae blooms when excess algae overflows the effluent weir. Dissolved 0xygen (DO) levels in the influent and effluent are also indicators of proper operation. Values for influent and effluent DO are shown in Figure 3-9. Figure 3-10 1ists the $\mathrm{pH}$ and Figure 3-11 represents STP volume.

\subsection{ICPP Injection Well}

The ICPP injection well was permanently sealed in November 1989. 
Table 3-4

ICPP PRODUCTION WATER WELL CY-1994

(mg/L)

\begin{tabular}{|c|c|c|c|c|c|c|c|c|c|c|c|c|c|}
\hline $\begin{array}{l}\text { INORGANIC } \\
\text { CHEMICALS }\end{array}$ & JAN & FEB & MAR & APR & MAY & JUN & JUL & AUG & SEP & ocr & Nov & DEC & $\begin{array}{c}\text { MAXIMUM } \\
\text { CONTAMINANT } \\
\text { LEVEL }\end{array}$ \\
\hline Arsenic (As). & & & & & & & & & & & & & $5.00 \mathrm{E}-02$ \\
\hline Barium $(\mathrm{Bg})$ & 8.69E-02 & 8.90E-02. & $8.53 \mathrm{E}-02$ & 8.17E-02 & 7.98E-02. & $7.98 \mathrm{E}-02$ & $.9 .02 \mathrm{E}-02$ & $8.48 \mathrm{E}-02$ & $8.66 E_{-02}$ & $8.68 \mathrm{E}-02$ & $.9 .48 \mathrm{E}-02$ & ‥03E-02. & $2.00 E+00$ \\
\hline Cadmium(Cd) & & & & $9.00 E-04$ & $4.00 \mathrm{E}-04$ & $.800 \mathrm{E}-04$ & & & & & & & $5.00 E-03$ \\
\hline .Chloride Ion & $1.84 \mathrm{E}+01$ & $1.75 \mathrm{E}+01$ & $1.81 \mathrm{E}+01$ & $1.76 \mathrm{E}+01$ & $1.84 E+01$ & $2.08 E+01$ & $1.71 E+01$ & $1.79 \mathrm{E}+01$ & $1.88 \mathrm{E}+01$ & $2.02 E+01$ & $1.77 \mathrm{E}+01$ & $1.60 \mathrm{E}+01$ & \\
\hline Chronium $(\mathrm{Cr})$ & $5.45 \mathrm{E}-03$ & 5.40E-03 & $6.20 \mathrm{E}-03$ & $5.60 \mathrm{E}-03$ & $6.20 \mathrm{E}-03$ & $6.20 \mathrm{E}-03$ & $6.05 E-03$ & $7.20 \mathrm{E}-03$ & $5.10 \mathrm{E}-03$ & $5.90 \mathrm{E}-03$ & $6.00 \mathrm{E}-03$ & $4.55 \mathrm{E}-03$ & $1.00 \mathrm{E}-01$ \\
\hline Fluoride lon & $2.16 \mathrm{E}-01$ & & $2.26 \mathrm{E}-01$ & $2.43 \mathrm{E}-01$ & $1.96 \mathrm{E}-01$ & $2.09 \mathrm{E}-01$ & $2.29 \mathrm{E}-01$ & $2.09 E-01$ & $1.99 \mathrm{E}-01$ & & & $2.04 \mathrm{E}-01$ & $4.00 E+00$ \\
\hline Lead $(\mathrm{Pb})$ & & & & $690 \mathrm{E}-03$ & & & & & & & & $5.32 E-02$ & $5.00 \mathrm{E}-02$ \\
\hline Mercury $(\mathrm{Hg})$ & & & & & & & & & & & & & $2.00 \mathrm{E}-03$ \\
\hline Nitrate Ion & $4.68 \mathrm{E}+00$ & $4.55 \mathrm{E}+00$ & $4.84 \mathrm{E}+00$ & $464 E+00$ & $4.57 E+00$ & $4.91 \mathrm{E}+00$ & $4.55 \mathrm{E}+00$ & $4.83 \mathrm{E}+00$ & $4.75 E+00$ & $4.73 \mathrm{E}+00$ & $4.65 \mathrm{E}+00$ & $4.64 \mathrm{E}+00$ & $1.00 \mathrm{E}+01$ \\
\hline Phosphate Ion & & & & & & & & & & & & & \\
\hline Selenium (Se) & & & & & & & & & & & & $2.50 \mathrm{E}-03$ & $5.00 \mathrm{E}-02$ \\
\hline Silver $(\mathrm{Ag})$ & & & & & & & & & & & & & \\
\hline Sodium. $\mathrm{Na})$ & $8.00 \mathrm{E}+00$ & $8.30 \mathrm{E}+00$ & $7.80 E+00$ & $7.20 E+00$ & $7.20 \mathrm{E}+00$ & $77005+00$ & $7.30 \mathrm{E}+00$ & $7.80 E+00$ & $7.30 \mathrm{E}+00$ & $7.80 \mathrm{E}+00$ & $750 \mathrm{E}+00$ & $8.10 E+00$ & \\
\hline Sulfate Ion & $2.34 \mathrm{E}+01$ & $2.57 \mathrm{E}+01$ & $2.71 E+01$ & $2.68 \mathrm{E}+01$ & $2.61 E+01$ & $2.67 \mathrm{E}+01$ & $2.49 \mathrm{E}+01$ & $2.67 \mathrm{E}+00$ & $2.80 \mathrm{E}+01$ & $2.76 \mathrm{E}+01$ & $2.59 \mathrm{E}+01$ & $2.60 \mathrm{E}+01$ & \\
\hline
\end{tabular}


Table 3-5

ICPP POTABLE WELL CY-1994

(mg/L)

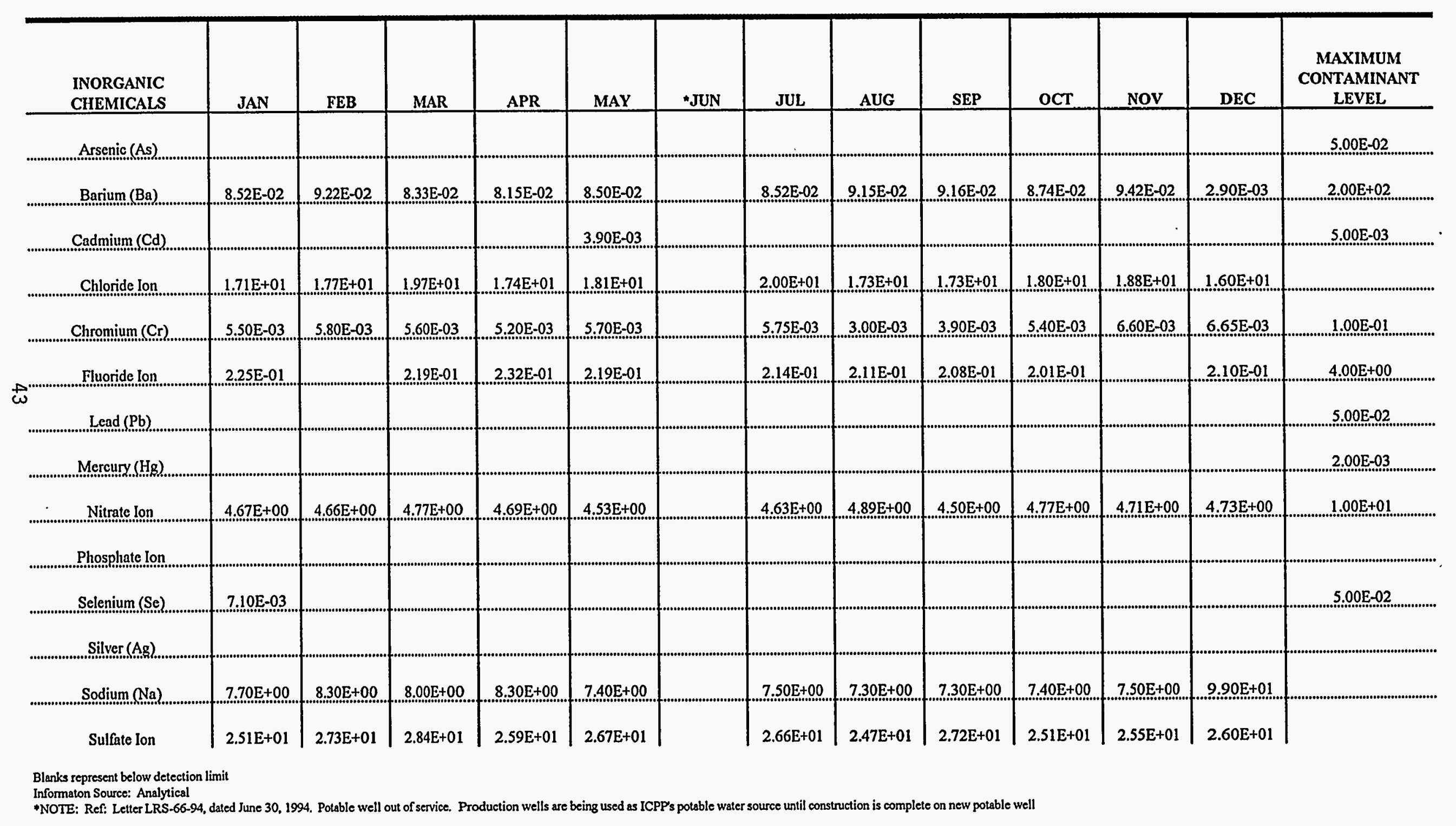




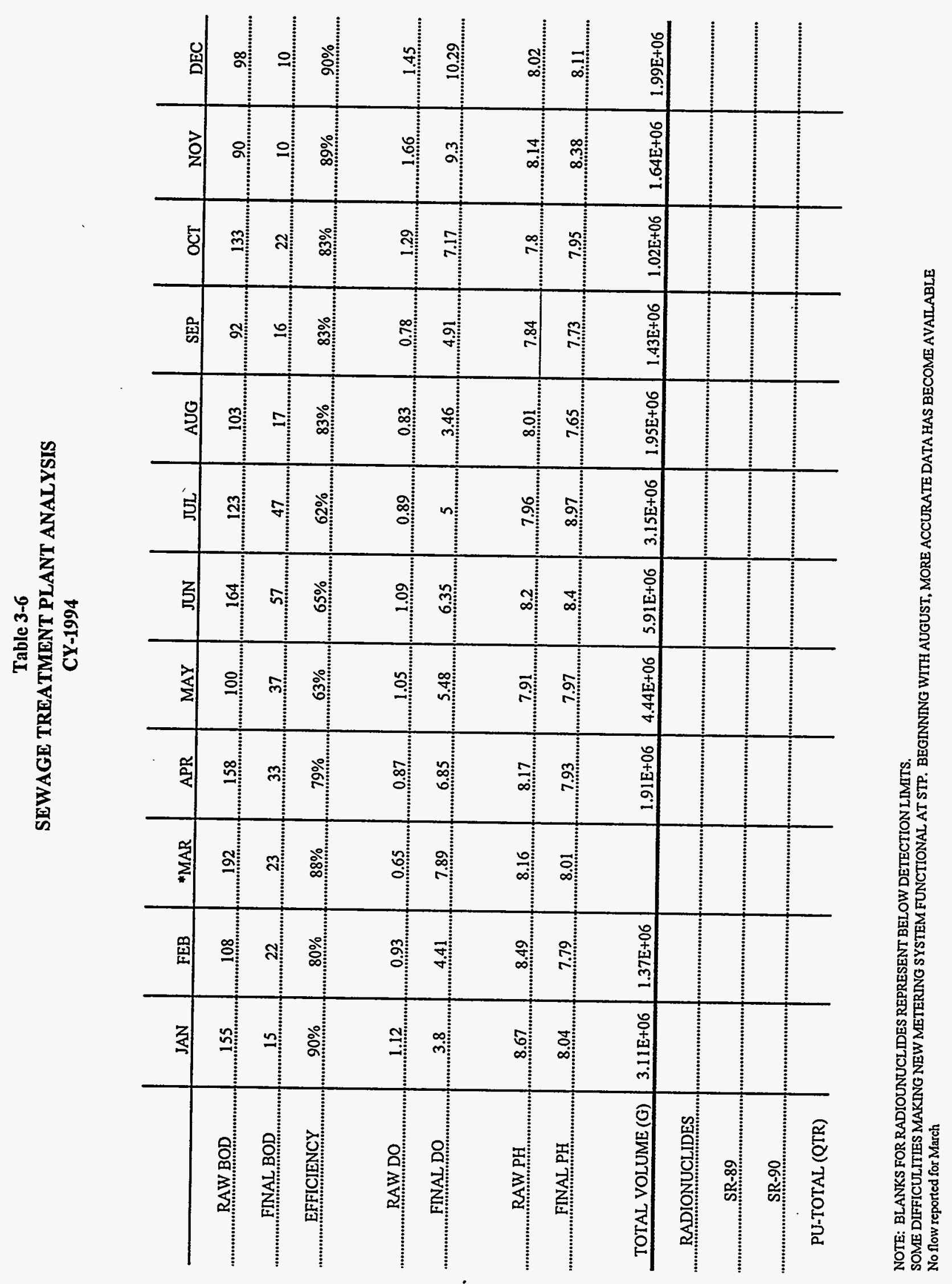




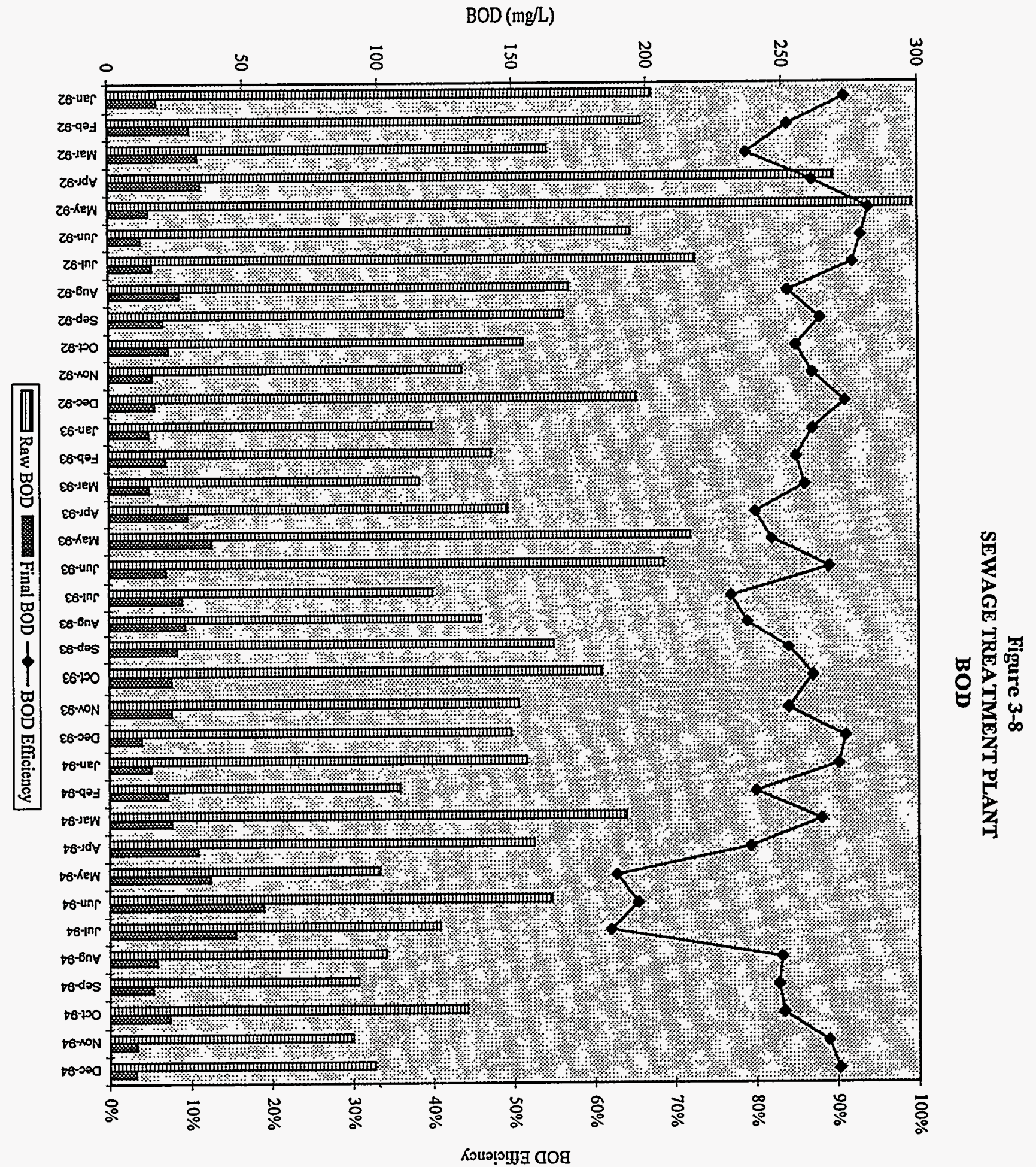




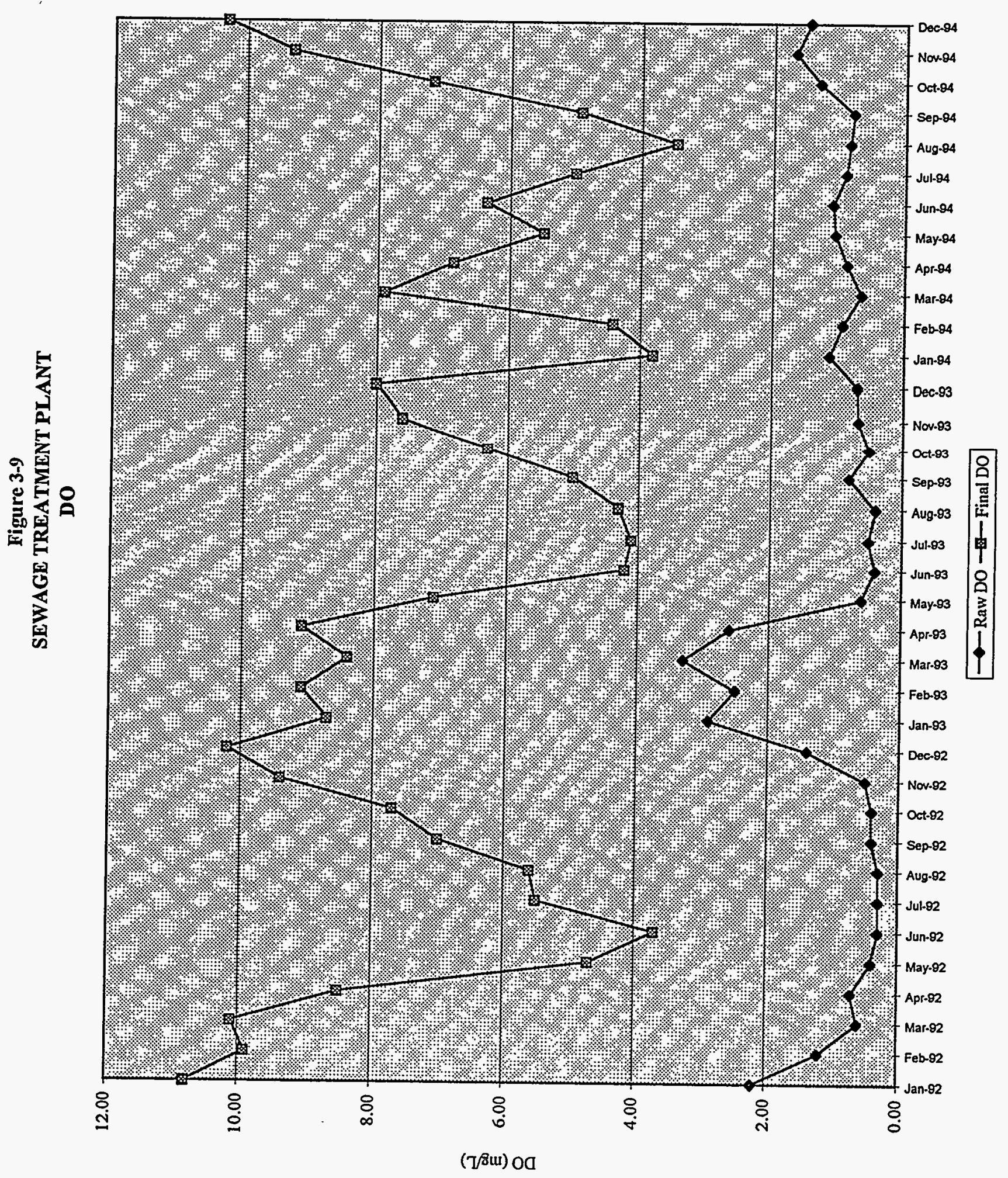




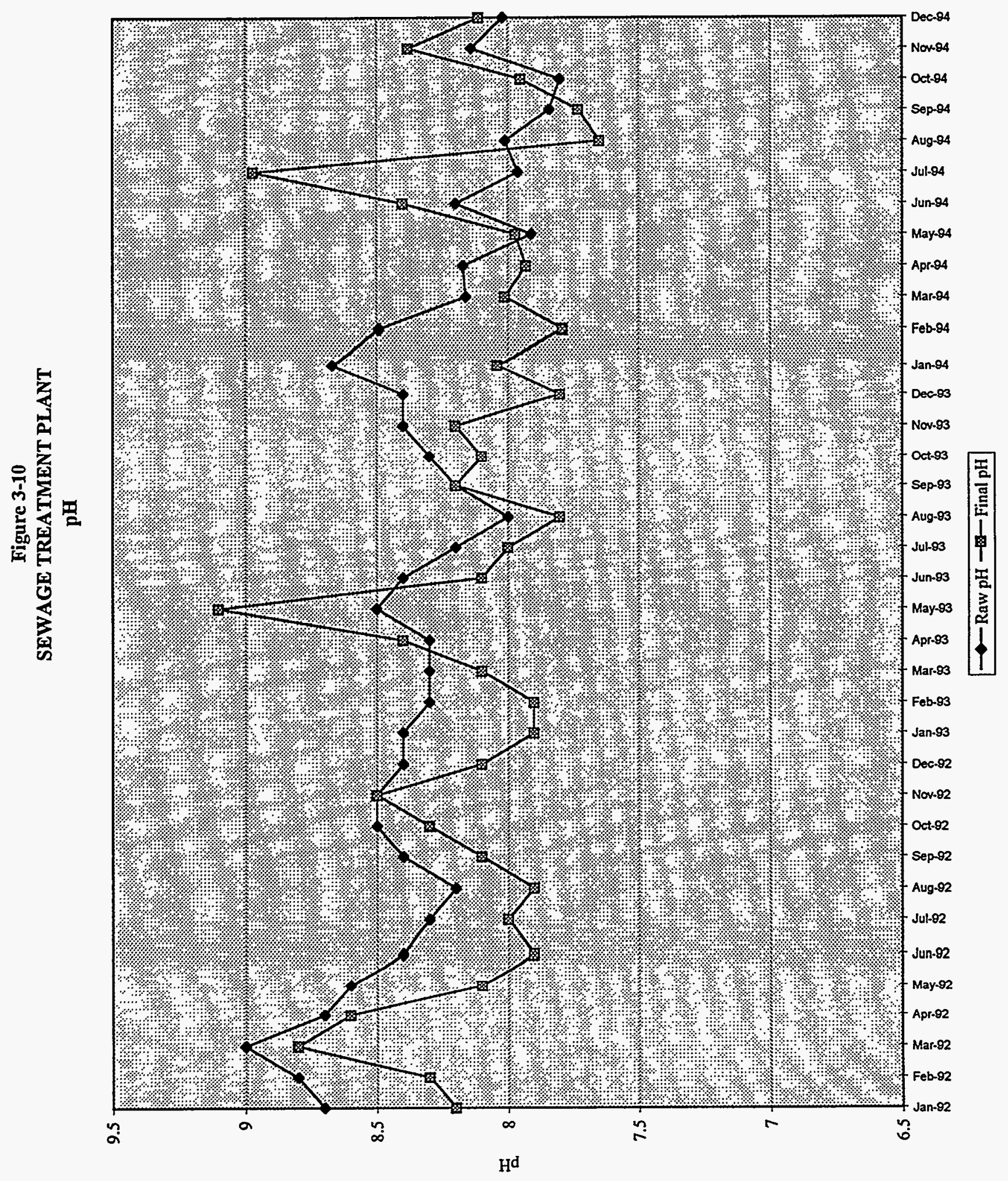


Figure 3-11

SEWAGE TREATMENT PLANT

Volume

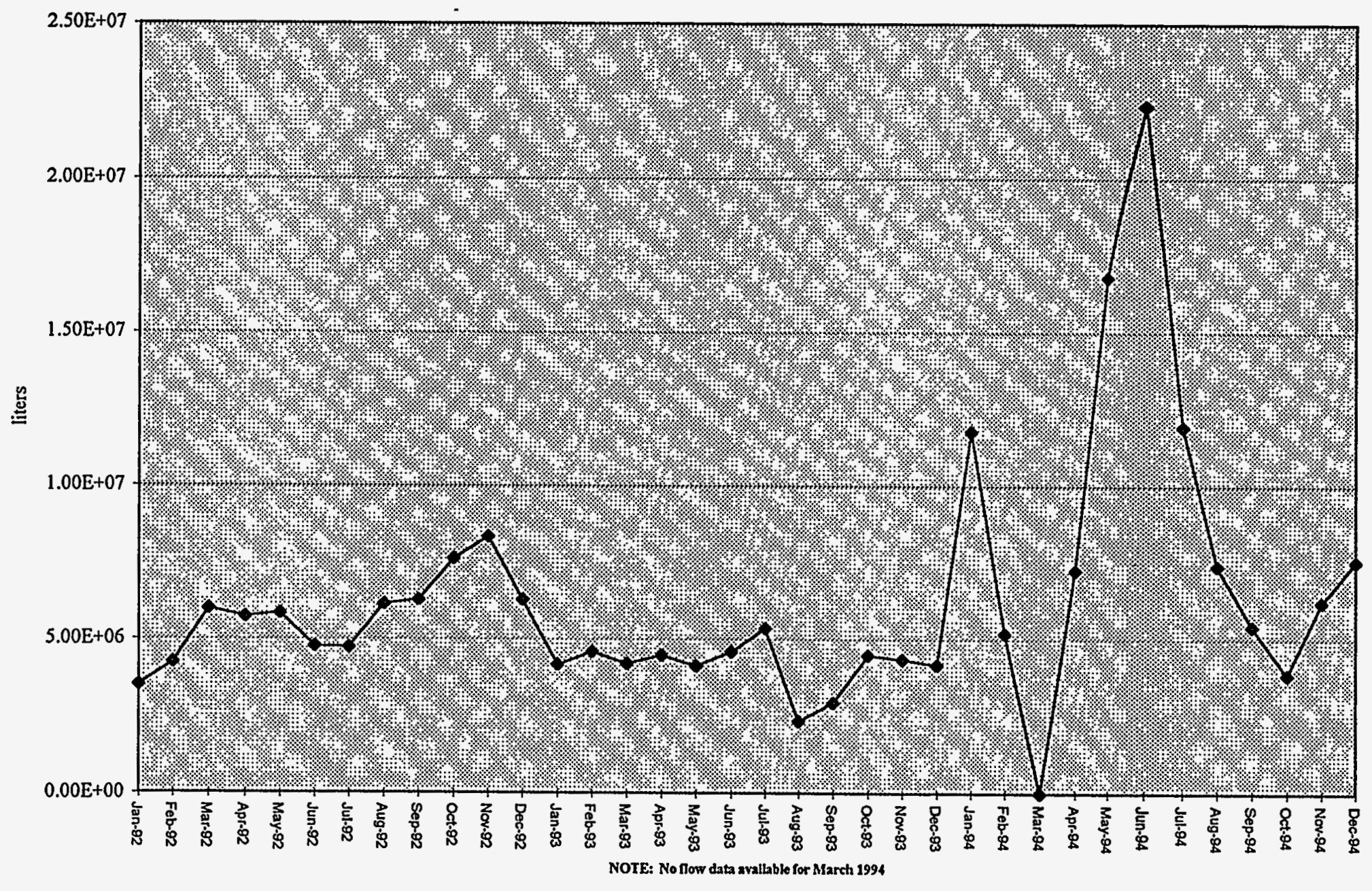

$\rightarrow$-Volume 